\title{
Eski Uygurca İyi ve Kötü Prens Öyküsü’nde Kahramanın Yolculuğu*
}

\author{
Hacer Tokyürek**
}

Özet: İnsanın en büyük amacı tanrıyı ya da belki kendini bulmaktır. Tanrıyı ya da kendini bulan kişi ebedi sükûnete ve özgürlüğe kavuşmuş olacaktır. Bu yüzden mitolojilerde/edebî metinlerde 'seçilmiş kahraman', 'büyülü nesne'yi bulmak için bir yolculuğa çıkar. Elbette ki bu arayış ve yolculuk kahraman için engellerle ve tehlikelerle dolu bir yolculuktur. Kişinin kendiyle hesaplaştığ tanrısal insan yarattığ mutluluğu elde edecektir. Kahraman artık benliğini öldürmüş, tüm duygularından ve arzularından kurtulmuştur. Sonuç: nihai kurtuluş. Eski Uygur Türkçesiyle yazılmış anlatıların pek çoğunda kahraman ve kahramanın yolculuğunu görmek mümkündür. $\mathrm{Bu}$ metinlerde yer alan kahramanların yolculuğunu takip etmek bu anlatıların daha iyi anlaşılmasını sağlayacağı gibi metinlerin semantik örgüsünü ortaya çıkarmak açısından da yardımcı olacaktır.

$\mathrm{Bu}$ düşünceden hareketle Eski Uygur Türkçesinin önemli metinlerinden biri olan İyi ve Kötü Prens Öyküsü'ndeki ana kahramanın yolculuğu ele alınmış ve bu yolculuk Joseph Campbell'in Kahramanın Sonsuz Yolculuğu adlı çalışmasına uyarlanarak tahlil edilmiştir.

Anahtar Kelimeler: Eski Uygurca, Eski Uygurca Anlatılar, Kahramanın Yolculuğu, Tanrısal Beden.

* Bu yazı TÜBA-GEBİP kapsamında hazırlanmıştır.

** Prof., Dr., Erciyes Üniversitesi, Edebiyat Fakültesi, Türk Dili ve Edebiyatı Bölümü, Kayseri/Türkiye. hacertokyurek@erciyes.edu.tr, htokyurek@hotmail.com. Orcid: 0000-0002-0008-1213.

Received: 07.12.2021; $\quad$ Accepted: 31.12.2021; 


\section{Abstract: The Hero's Journey in the Story of the Good and the Bad Prince in Old Uyghur}

Human's greatest goal is to find God, or perhaps himself/herself. Human who finds God or himself/herself will attain eternal peace and freedom. That's why the 'chosen hero' in mythologies/literary texts goes on a journey to find the 'magical object'. Of course, this quest and journey is a journey full of obstacles and dangers for the hero. The hero will attain eternal happiness at the end of this journey in which the person settles accounts with himself/herself, listens to himself/herself, even kills himself/herself and creates a new divine person. The hero has now killed his/her ego, freed from all his/her feelings and desires. The result: ultimate liberation. It is possible to see the hero and the hero's journey in many of the narratives written in Old Uyghur. Following the journey of the heroes in these texts will not only provide a better understanding of these narratives, but will also help to reveal the semantic pattern of the texts.

Based on this idea, the journey of the main hero in The Story of the Good and the Bad Prince, one of the important texts of Old Uyghur Turkish, was discussed and this journey was analyzed by adapting it to Joseph Campbell's The Hero's Endless Journey.

Keywords: Old Uyghur, Old Uyghur Narratives, Hero's Journey, Divine Body.

Giriş Dinlerde ve mitolojilerde/edebî metinlerde yol ve yolculuk önemli bir kavram olup 'seçilmiş kahramanlar'ın yolculukları her zaman tehlikelerle doludur. Bir Hint metninde ' $\mathrm{Bu}$ tehlikeli bir yoldur, bıçak sırtı gibi.' şeklinde yazar (Campbell-Moyers 2020: 173). 'Çünkü aslında bu yol dindışı olandan kutsal olana bir geçiş ayinidir; geçici ve aldatıcı olandan gerçekliğe ve ebediliğe; ölümden hayata; insandan ilahlığa.' olan bir yolculuktur (Eliade 2020: 31). Bu yolda yolculuk yapacak kişinin 'seçilmiş bir kahraman' olmas1 gerekmektedir. Onun gerekli cesarete, bilgiye ve kapasiteye sahip olması beklenir. Sınavların da amacı kahramanın bu konuda sınanmasıdır. Bununla birlikte kahraman bir başkasına hayat vermek için kendinden vazgeçme erdemine sahip olmalıdır. Burada kendimizi korumayı düşünmekten vazgeçtiğimiz zaman gerçek ve kahramanca bilince ulaşmış oluruz. Bunu da gerçekleştirmek için 
kahramanın alışık olduğu emniyetli hayatını bırakması gerekir (Campbell-Moyers 2020: 166-167). Kahramanın kendini feda edip veya kurban edip yolculuğa çıkması için büyük bir amacı olmalıdır. Örneğin İnanna'nın yeraltına inmesinin nedeni sevgilisini hayata döndürme istediğidir. O sevgilisi için ölüme gider (CampbellMoyers 2020: 170). Bunun gibi pek çok mitolojik kahramanların da yolculuğa çıkış sebebi vardır. En önemli yolculuklar arasında sayılan Śākyamuni Buddha'nın yolculuğu da bir sebebe bağlıdır: tüm canlıları 1zdıraplardan kurtarmak ve onları sonsuz özgürlüğe ulaştırmak. Böylece Buddha'nın yolculuğu başlar. Buna göre; Siddhārtha Gautama (Buddha) henüz doğmadan önce babası Śuddhodana bir kâhine gider ve oğlunun geleceği hakkında bilgi almak ister. Kâhin bu çocuğa çizilmiş olan kaderden bahseder ve Buddha'nın babası oğlunun dünya fatihi olması ve dinî bir lider olmaması için oğlunu sarayda her türlü zevk ve eğlence içinde yetiştirir. Fakat ona çizilen kader bambaşkadır. Güvenli hayatından çıkan Siddhārtha Gautama hasta, yaşlı, ölü ve son olarak bir dilenci görür ve bu durumdan sonsuz ızdırap yaşar. Erginliğe ulaşmak için 29 yaşında bir gece oğlunu ve karısını terk ederek beyaz atına ${ }^{1}$ biner ve ormana doğru yol alır. Ormanda pek çok münzevi ile tanışır, onların erginleşme için uyguladıkları yöntemleri uygular. Fakat hiçbirinde başarılı olamaz. Açlıktan ölecek bir durumdayken köylü bir kızın ${ }^{2}$ Buddha'ya bir kâse pirinç lapası vermesi onu gerçekliği anlaması konusunda uyarır, uyandırır. Lapayı yemesi sonucunda Buddha'nın etrafindakiler onu terk eder. Artık ormanda yapayalnız ${ }^{3}$ kalmıştır. Onun yalnız kalması aydınlanmasını da kolaylaştıracaktır. O bir gece bo/bodhi ağacının altına oturup erginlenmeyi beklerken bu defa Māra harekete geçer ve tüm ordularını Buddha'nın üzerine gönderir. Fakat Māra bu saldırısında başarısız olur ve artık Siddhārtha Gautama, Buddha olur. Dönüş vakti gelmiştir (Tokyürek 2019a: 72-73). Yaşadığı bölgeye dönen Buddha insanlara gerçeği anlatıp onları içinde bulundukları 1z-

\footnotetext{
${ }^{1}$ Beyaz at düşüncesi önemlidir. Çünkü bu at olağanüstü özelliklere sahiptir. Bu atı bir rehber ya da bir hâlden bir hâle geçişe yardımcı bir varlık olarak düşünmek mümkündür.

${ }^{2}$ Bu köylü kız, onun gerçeği anlaması için gönderilen bir rehberdir.

${ }^{3}$ Erginleşmek için kahramanın yalnız kalması gerekir. Mitlerde ve dinlerde kahraman/peygamber erginliğe ulaşması için yalnız kalması elzemdir. Örneğin Odisseus kıyıya çıktı̆̆ında 'Sonunda yalnızım, sonunda yalnızım.' der (Campbell-Moyers 2020: 176).
} 
dıraplı dünyadan kurtarabilmek için mücadele eder. Onun amacı tüm canlıları kurtarıp onları özgürleştirmektir. Śākyamuni Buddha'nın bu mitsel yolculuğu 'ayrılış, başarı ve dönüş’ten oluşan bir döngüdür.

Iyi ve Kötü Prens Öyküsü’nde de İyi Prens Śākyamuni Buddha ile özdeşleştirilmelidir. Çünkü İyi Prens Çin. 能施太子 néng shī tàiž 'verici, verebilen' olarak tanımlanır ve Śākyamuni Buddha'nın inkarnasyonlarından biri olarak gösterilir (SoothillHodous 1937: 337a). Bu hikâyede de 'İyi Prens'in yolculuğa çıkma nedeni insanları daha doğrusu tüm 1zdıraplı canlıları 1zdıraplarından kurtarıp onları sonsuz özgürlüğe kavuşturmaktır. Kahramanı yolculuğa zorlayan toplumdaki kaotik ortamdır, canlıların farkındalıktan yoksun olmalarıdır. Bundan kaynaklı olarak da mitlerde ve dinlerde kahraman/peygamber bir yolculuğa daha doğrusu ruhsal bir yolculuğa çıkar. Onun amacı önce kendi erginliğini elde etmek, sonrasında elde ettiği ödül ile tüm insanlığı kurtarmaktır. Kahramanların/peygamberlerin tüm yolculuklarında da durum hep aynı olmuştur. Bunun için kahramanın genel bir yol izlemesi gerekir: ayrılış, başarı, dönüş (Campbell-Moyers 2020: 178).

\section{Yola Çıkış}

\subsection{Maceraya Çağri/Kaos}

Büyük Patlama Teorisine göre evrenin yaratılışı bir kaos/kriz neticesindendir. İnsanın var oluşu da tıpkı evrenin var oluşu gibi kaos ortamının oluşması sonucundadır. Kaos sözü, sözlük anlamıyla 'evrenin düzene girmeden önceki biçimden yoksun, uyumsuz ve karışık durumu, kargaşa' ${ }^{4}$ olarak tanımlanırken bilimsel anlamda ise 'düzensizliğin içindeki düzen'i (Öge 2005: 286) ifade eder. Campbell'e göre mitolojik kahramanın da yolculuğa ya da maceraya başlaması evren ve insanın var olması gibi bir 'maceraya çağrı'nın sonucunda gerçekleşir. Ona göre, 'kaza bir kaderin boy vermesini sağlayabilir.' (Campbell 2020: 55). Olayların ortaya çıkışının yol açtığı kriz 'maceraya çağrı'dır. Bu maceraya çağrı yani kriz ortamı aydınlanmanın şafağının belirtileridir. Mistik anlamda ise 'benliğin uyanması'nı ifade eder (Campbell 2020: 55). Başka bir ifade ile tanrısal bedeni elde etme yolundaki ilk aşamadır. Bununla birlikte bu ilk aşama 'kahramanı çağıran ve

\footnotetext{
${ }^{4}$ https://sozluk.gov.tr/ (Erişim tarihi: 01.12.2021).
} 
ruhsal ağırlık merkezini toplumunun sınırlarından bilinmeyen bir bölgeye doğru çekmiş olan kaderi belirtir' (Campbell 2020: 60). Śākyamuni Buddha'nın doğmadan önce belirlenmiş olan kaderi gibi aynı şekilde mitolojik kahramanın da kaderi önceden belirlenmiş ve kahraman bu kaderi yaşamak durumunda kalmıştır. Dolayısıyla Buddha'nın kaderini yaşadığı gibi herkes kaderini yaşar.

İyi ve Kötü Prens Öyküsü’nde de kahraman aslında kendine biçilmiş kaderi yaşamaktadır. Hikâye Śākyamuni Gautama Buddha'nın sarayından çıkıp gerçek dünya ile yani hasta, yaşlı, ölü ve dilenci ile karşılaşması sahnesiyle benzerlik gösterir. Śākyamuni Buddha sarayında tüm arzularını doyurmuş, her şeyi elde etmiş bir hayattan sonra, dış dünyaya açılmış ve bunun sonunda gerçek dünyayı görüp algılamış kısacası bir kriz/kaos ortamını fark etmiştir. İyi ve Kötü Prens Öyküsü'nde de durum aynıdır. Hikâyeye göre;

taşgaru ilinçüke atlanturdı erti balık taştın tarıgçılarag körür erti kurug yérig suvayu öl yérig tarlyu kuş kuzgun sukar yullyur sansız tümen özlüg ölürür tarıg tarıyu amarl ${ }^{5}$ tınlıglarıg kuşçı kèyikçi balıkçı avçı torçı tuzakçı bulup ayıg kılınç kılur tınlıglarag

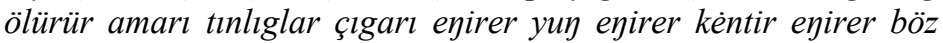
batatu kars toklyur takl yeme adrok uzlar kentü kentü uz işin işleyür adrok adrok emgek emgenür takl yeme kördi amarı tınlıglar yunt ud çokar koy lagzın ulatı tınlıglarıg ölürür terisin soyar kan ügüz akıtar etin kanın satar anın öz igidür yeme

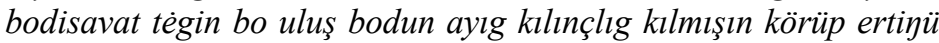
busuşluk kadgulug bolup ıglayu balıkka kirdi (I-IV) ${ }^{6}$

Prens güvenli sarayından dış dünyaya eğlenmek için çıkar fakat gördüğü sefalet manzarası karşısında dehşete kapılır. Çünkü tarım, hayvancilik ve avc1lık yapan insanlar binlerce hatta on binlerce canlının ölümüne neden olur. Tüm bunlarla birlikte diğer meslek erbapları da yaşamlarını sürdürebilmek için çıkrıklarını çevirir, yünlerini eğirir, kumaşlarını dokur, zanaatlarını yaparlar. Burada silsile hâlinde hem kötü eylemler hem de dayanılmaz ızdıraplar söz

\footnotetext{
5 Metinde emeri şeklinde olup burada düzeltilmiştir. Konuyla ilgili bk. (Röhrborn 2015: 124-126)

${ }^{6}$ Çalışma boyunca 'Hamilton, James, 2020: Budacı Iyi Kalpli ve Kötü Kalpli Prens Masalının Uygurcası, Prens Kalyānamkara ve Pāpamkara Hikâyesi, (Çev. Ece Korkut-İsmet Birkan), Türk Dil Kurumu Yayınları, Ankara.' adlı eserden alıntılama yapılmıştır. Bununla birlikte metinde bulunan bazı kelimelerdeki è/e, i/è, o/u, ö/ü, g/k ile ilgili hususlarda Röhrborn 2010, 2015, 2017 ve Wilkens 2021 adlı eserlerden faydalanılmıştır.
} 
konusudur. Dolayısıyla prensin görmüş olduğu bu manzara hem bir günah sahnesini hem de canlıların ızdırap içerisinde kıvrandığ manzarayı anımsatmaktadır ve tüm canlılar ızdırap içindedir. Fakat kurtuluş için kendileri hiçbir şey yapmamakla birlikte içinde bulundukları durumdan da habersizdirler. Bunun yanı sıra durumdan rahatsız olan, canlıların ızdırap çektiğini gören tek kişi ise 'İyi Prens'tir. Campbell'e göre hikâyede bu kaotik ortamda günahkâr ve acı çeken canlılar 'haberci', içinde bulunulan durum ise 'maceraya çağrı' dır (Campbell 2020: 55). Prens bu ortamdan tıpkı Śăkyamuni Buddha gibi tüm 1zdırapları içinde hissederek güvenli sarayına büyük bir üzüntü ile ağlayarak geri döner. 'İyi Prens' artık her şeyi görmüş ve her şeyin farkındadır. O, bu hayattaki gerçeklikten rahatsızdır.

Prens ağlayarak güvenli sarayına döndükten sonra, oğlunu büyük üzüntü içinde gören hükümdar oğluna neden ağladığını sorar. Prensin vermiş olduğu cevap ızdırabın kaynağını göstermesi açısından oldukça önemlidir. Buna göre;

ol üdün maharlt èlleg edgü ögli tèginig busuşlug körüp inçe tèp

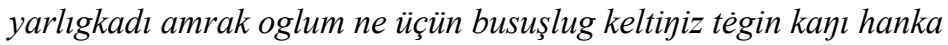
inçe tèp ötünti ılayu bo ne emgeklig yèr èrmiş negülük ${ }^{7}$ tugdum men kayı han inçe tèp ayıttı neke ılayu buşuşlug keltị tègin inçe tèp ötünti taştın ilinçüke ünmiş èrdim üküş yok çıgay emgeklig tınlıglarag körüp ıgladım (IV-V)

Prens babasına 'burası ne kadar acı dolu bir ülkeymiş! Niçin doğdum ben' (Hamilton 2020: 32-33) cevabını verir. Bu cevap 1zdırapların kaynakları arasındadır. Çünkü varoluş zincirinin ikinci ya da on birinci sırasında olan doğum, Budizm'de büyük ızdıraplar içerisinde gösterilir ${ }^{8}$. Kişinin doğmasına neden olan şey cehaletidir, kurtuluşu elde edemeyişi, gerçeği kavrayamayışıdır (Tokyürek 2019a: 308-310). Dolayısıyla özellikle bilinçsiz olarak doğmak büyük bir 1zdıraptır. Fakat 'İyi Prens' bu defa bilinçli doğum

\footnotetext{
${ }^{7}$ Metinde neglük şeklinde olup düzeltilmiştir. Bk. (Wilkens 2021: 489)

${ }^{8}$ Eski Uygurcada tugmak emgeki* 'doğum 1zdırabı' olarak belirtilen terim Skr. jati-duhkha'dır ve bu terim Eski Uygurcada taki y(e)me kim tugmak ajunug tutsar alku emgek tutmış bolur tugmak ajunug ldalasar alku emgekig ıdalamışka sanur (Tekin 1980: 131V17-21) 'Ve yine kim doğum varlık şeklini tutsa bütün 1ztırapları tutmuş olur, (canlı) doğum varlık şeklini terk etse, bütün 1ztırabı da terk etmiş olur.' (Tokyürek 2019a: 27-28) şeklinde de ifade edilir. Ayrıntılı bilgi için emgek kelimesi bk. (Röhrborn 2017: 190-197).
} 
yolunu tutmuştur ve kendisine çizilen kaderi yaşayarak yeniden doğacaktır.

Bununla birlikte prensin duymuş olduğu 1zdıraplardan biri de yok çıgay emgeklig tınlıglarag 'fakirlik içinde 1zdırap çeken canlıları' görmüş olmasıdır. Metinde canlıların maddi sıkıntılarından söz etmek yanlıştır. Çünkü hikâye incelendiğinde herkes bir uğraş içindedir ve hiç kimse maddi olarak sıkıntıda değildir. Öyküdeki sıkıntının asıl kaynağı 'ruhsal yoksunluk' ya da diğer bir deyişle 'cehalet'tir. Canlıların hiçbiri içinde bulundukları ortamdan haberdar değildir, farkındalıkları yoktur, sadece işlerini yapıp yaşamlarını sürdürmektedirler. Varoluşun zinciri olan nidāna'nın da ilk halkası işte bu cehalettir ${ }^{9}$. Böylece prensin görmüş olduğu kaotik ortam canlıların gerçek olayların doğasını anlamayıp var olmayan şeylerle uğraşmalarından kaynaklanan bir kriz ortamıdır.

\section{2. Çağrının Reddedilişi}

Campbell'e göre yolculuğa çıkışın ikinci aşaması 'çağrının reddedilişi'dir. Ona göre mitolojik kahraman çoğu kez kendisine yapılan çağrının farkında olmaz ve bu yüzden kendine yapılan çağrıyı bilinçli ya da bilinçsiz bir şekilde reddeder. Kahramanın çağırıya olumlu cevap vermeyerek başka ilgilere yönelmesi her zaman olası bir davranıştır. Bunun sonucunda çağrının reddi macerayı olumsuza çevirir. Belirgin olumlu eylem gücünü kaybeden kahraman, kurtarılacak bir kurban olur. $\mathrm{O}$ artık labirenti içerisinde kendisi için yeni sorunlar yaratacak ve bu sorunlar içerisinde ezilmeyi bekleyecektir. Yolunu kaybetmiş ruhunun kilitli labirenti içinde yaşayan o benlik imgesi tanrısal varlık tarafından

\footnotetext{
9 'Budizm'de cehalet, diğer halkaların oluşmasına neden olur ve canlıların saṃsārada yeniden doğmalarını sağlar. Canlıların saṃsāradaki tüm yanılsamaları ve hastalıkları bu cehalet sebebiyle ortaya çıkar. Cehalet, varoluşun gerçek doğasını bilmemekten kaynaklanır ve böylece gerçekliğin doğru doğası kavranmamış olur. Bu nedenle de cehalet, canlının mutlu olmasının ve acı çekmesinin ana sebebidir. Cehaletin en önemli yanı, olayların gerçek doğasını anlamayarak var olmayan şeylerle meşgul olmasıdır. Her şey geçici olmasına rağmen her şeyin kalıcı olduğuna inanılmasıdır. Cehalet, bir kafa karışıklığı olarak da ifade edilir (Rinpoche 1993: 5-6)’ (Tokyürek 2019a: 311). Ayrıca cehalet, nidāna'nın ilk halkası olmasıyla birlikte Budizmde üç zehir arasında da sayılır ve canlıların günah işlemesine neden olur. 'Izdırabın ve ahlâksızlığın üç zehrinden biridir. Aldatma, cehalet ya da yanlış düşünce ve aydınlanmamayı ifade eder (Soka Gakkai 2002: foolishness mad.; ER, Avidyā II, 17-18)' (Tokyürek 2019a: 42).
} 
kovalanacaktır. Fakat kapılara giden yollar artık görünmez olmuştur (Campbell 2020: 61-62).

Buna göre hikâyede prens ve hükümdar ilk olarak bu ruhsal yoksunluktan kaynaklı olan cehalet ve sefalet ortamını yani krizi anlamaz ve 'gerçeği' kavramazlar. Bununla birlikte prensin babası / hükümdar bu gerçeği hiçbir zaman göremeyecek ve kavrayamayacaktır. Hikâyede hükümdar canlıların maddi ve/veya ruhsal yoksunluklarından kaynaklı olarak çekmiş oldukları ızdıraplarıyla bir nevi ilgilenmez. Çünkü bu durumun onların kaderi olduğunu, dünya yaratıldığından beri zenginliğin ve fakirliğin olduğunu düşünür. $\mathrm{Bu}$ da hükümdarın canlıların 'maddi' ve/veya 'ruhsal yoksunluk'larının da olabileceğini hiç düşünmediğinin bir göstergesidir.

kayı han inçe tèp yarlıkadı amrak ögüküm yèr teyri törümişte berü bay yeme bar yok çıgay yeme bar kayusıja emgekte ozgurgay sen $(\mathrm{V}-\mathrm{VI})$

Macerayı bilinçsiz bir şekilde reddeden prens de canlıların ruhsal yoksunluğundan ziyade maddi yoksunluk içinde olduklarını düşünür. $\mathrm{Bu}$ da onun macerayı reddetmesinin ya da çağrıyı anlamamasının bir göstergesidir. Prens gerçeği kavrayamamış, gerçek 'uyanış'a ulaşamamıştır.

ol edgü kü at tört buluyda yadıltı künine kolguçılar üzülmedi

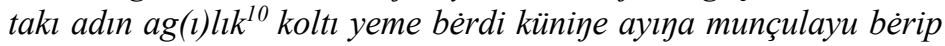
aglıktakı agı barım azkına kaltı (VII)

ol üdün agıçı ulugı hanka inçe tèp ötünti teyrim ag(l)lık kurug bolkalır agl barım alkınsar uvatsar yazukka tüşe téginmegey ertimiz (VII-VIII)

yeme kayı han inçe tèp yarlıgkadı kay kazgansar oglı üçün

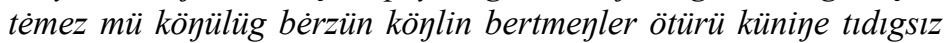
bèrdi (VIII)

ol üdün kayı han inçe yarlıgkadı amrak ögüküm köylin neçük berteyin men agıçı başçısı agıçılar birer üdün öyi barzun kentü bilingey érinç tèp yarlıgkadı anta ötrü koltguçılar kelser agıçılarnın bulmaz erti bèrgü bulmatın koltguçılar yıglayu barsar tégin yeme iglayu kalır erti (IX-X)

Metinden anlaşıldığı kadarıyla prensin babası hükümdar tüm hazinelerini oğlunun isteği uğrunda dağıtmaya başlar. Hikâyede

${ }^{10}$ Metinde aglık şeklinde olup burada düzeltilmiştir. Geniş bilgi için bk. (Röhrborn 2015: 57-60). 
ülkede ne kadar dilenci, fakir varsa hazineden pay almak için buraya gelir ve tükenen hazinelerin yerine başka hazineler dağ1tılmaya başlanır ki artık dağıtılacak hazine kalmayıncaya kadar bu durum devam eder. Burası tam bir çıkmazdır. Çünkü Campbell'in dediği gibi kahraman başka ilgilere yönelmiş ve kendi çıkmazı içerisinde dönüp durmaktadır. Kahraman hâlâ gerçeği kavramaz. Prens farkında olmadan kaderini reddeder. 'Öngördüğü yaşam rolüne geçmede başarısız olur... Tanrısallığın kendisi onun korkusu olur, çünkü eğer kişi kendisinin tanrısıysa Tanrı'nın kendisi, Tanrı iradesi, kişinin benmerkezci sistemini yıkacak olan o güç, bir canavar hâline gelir.' (Campbell 2020: 62). Hikâyeye göre artık yavaş yavaş hazine tükenmeye başlar ve dilenciler hazinedarları yerlerinde bulamazlar. Prens babasının halkın dilinden/dedikodularından korktuğu için hazinedarlara emir verdiğini ve bu yüzden hazinedarların görevlerini yapmadığını düşünür. Ancak hazinenin tükenmesi aslında 'maceraya çağrı'ya cevap vermeyen prense 'ikinci çağırı'dır. Eğer hazine tükenmese ya da hazinedarlar ve hükümdar hazine dağıtımına müsaade etse prens 'maceraya çağrı'ya hiçbir zaman yanıt vermeyecektir. Fakat özellikle hükümdar farkında olmadan oğlunun kaderini yaşamasının yolunu açmıştır. Tıpkı Śākyamuni Buddha'nın babası Śuddhodana'nın oğlunun kaderini yaşamasına farkında olmadan müsaade etmesi gibi.

kayım han bodun tiline korkup inçe yarligkadı érinç közünür at

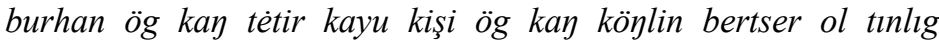

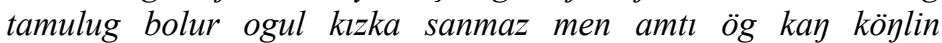
bertmeyin kayım èllig tilke kirmezün öz kazgançım üze edgü kilınç kılayın tèp sakıntı (XI-XII)

Hâlâ gerçeğin farkındalığına ulaşamayan prens anne babasına söz gelmesin, onların gönlü kırılmasın diye kendi hazinesini oluşturmaya çalışacaktır. Bunun için de ülkenin önemli kişilerinden zenginlik için çeşitli öneriler alacaktır. Buna göre;

anta ötrü atlig yüzlügke inçe tèp aylttı neçükin agl bartm kazgansar üküş bulur atllglar inçe tép ötünti öyi öyi kazganç kılmak ayu bèrdiler biri ayur kazganç nè tarı tarımakda edgü yok kim bir tarısar min tümen bulur biri ayur koy yllkn égidser yllina astlur bay bolur biri ayur öytün kédin sattgka yulugka barsar bay bolur (XII-XIV)

Hikâyede verilen üç öneri de tamamıyla maddi kazanç ile ilgilidir. Çünkü hiçbiri gerçeği kavrayamamış ve bu yüzden prensin 
de kendi bildikleri doğrultusunda hareket etmesini salık vermişlerdir. Prens kendi ve etrafının oluşturduğu labirentte dolaşmaya devam etmektedir. Gerçeği görmesi için hâlâ bir çıkış yolu gözükmemektedir ki bilge, yasa/öğreti bilir bir kişinin önerisi her şeyi değiştirecek boyuttadır.

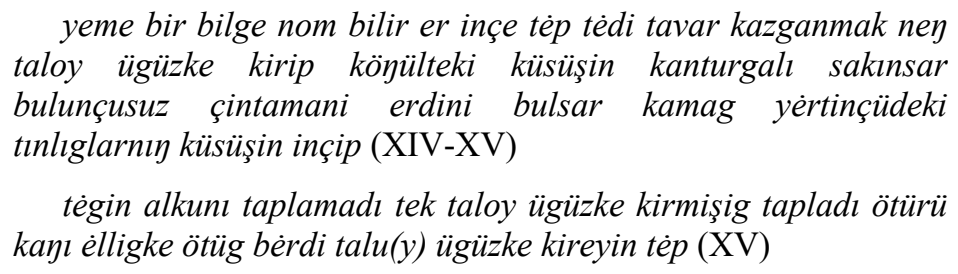

$\mathrm{Bu}$ kişi kahramanın farkındalığını artıran, bir nebze uyanmasını sağlayan yaşlı bilge arketipidir. Bilgenin yaşlı olup olmadığ belirtilmezken onun öğreti bilmesi diğerlerinden farklı olduğunun bir göstergesidir. Campbell'e göre o 'bizi bekleyen kısmeti ve hazinelerle dolu kaleyi haber veren' kişidir (2020: 18). Yukarıda da bahsedildiği üzere ilk üç kişi, prense maddi kazanç elde edebilecek yollar sunarken bu bilge, yasa bilir kişi ise prensi 'canlıların tüm arzularını yerine getirebilecek' cintāmaṇi mücevherini bulması yönünde öğütlerde bulunur. Labirentin ucunda bir 1şık görülmektedir. Prens artık ne yapacağını, ne yapmak istediğini bilmektedir. Hedef cintāmaṇi'yi bulup tüm canlıları bu sefalet ortamından kurtarmaktır. Fakat en büyük engel yine anne ve babasıdır. 'Baba ve anne eşik muhafızları olarak durur ve birtakım cezalardan korkan, çekinen ruh, kapıdan geçmeyi ve dışarıdaki dünyaya doğmayı başaramaz.' (Campbell 2020: 64). Hikâyede de kahramanımız bilge kişinin sözü doğrultusunda hareket etmek istediğini belirttiğinde babası oğluna yeni hazineler vermeyi vaat eder. Daha önce dedikodulardan çekindiği için hazine yardımını kesen baba, oğluna engel olmak için hazinesini tekrar ortaya koyar. Bu kahramanın labirentten çıkışını engellemek için oluşturulmuş son aşamanın ilk engelidir.

ötrü ol ogl tèginke inçe tép yarligkadı amrak ögüküm menin

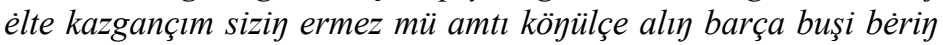
ne üçün ölüm yèrke barır siz (XVI)

Hikâyenin devamında ise baba kahramanın gideceği yolu 'ölüm yeri' olarak belirtmektedir. $\mathrm{Bu}$ da son aşamanın ikinci engelidir. Burada kullanılan 'ölüm yeri' ilginç olmakla birlikte bilinen bir metafordur. Campbell'e göre bilinçdışılık akla her türlü korkutucu 
ve ürkütücü imgeyi gönderir. Ona göre insan, akla hayale gelmeyen masal mağaralarına iner ve orada yalnız mücevherler değil, tehlikeli cinler ve daha başka korkunç güçler bulunur (Campbell 2020: 17). Bununla birlikte 'ölüm yeri' ifadesi kahramanın ölüler diyarına gitmesini de ifade eder. Çünkü genel olarak kahramanın erginliğe ulaşması için yer altına ya da tehlikelerle dolu yola çıkması gerekmektedir. Bu durum akla İnanna'nın yolculuğunu getirmektedir. İnanna başkalaşım kapılarından geçmek için bu 'dönüşü olmayan ülkeye' yolculuk yapar (Campbell 2020: 99). Bu yer altına iniş Şamanist uygulamalarda da vardır ve Şamanın yeraltına yapmış olduğu ruhsal yolculuk neticesinde o, hastalıkları tedavi etmeyi öğrenir (Eliade 2018: 69) kısacası ruhsal değișime uğrar. Böylece kahraman kendisi için büyük tehlikeler yaratan bir yolculuğa çıkacaktır ve bu yolculukta başarısız olma ihtimalinin yanında ölme ihtimali de çok yüksektir. Bu yüzden hükümdarın oğlunun yolculukta başına gelebilecek tehlikeleri sıralaması dikkat çekicidir.

bèş törlüg ada bar bir ada ol èrür talım ballk odug erken saklanmadın tuşar alkunı kèmi birle sịürür èkkinti suvda suv öylüg taglar bar kèmi süsüp sinur kişi alku ölür üçünç suvda yekler urup kèmi suvka çomurur törtünç ulug tegzinç ... kigürür suv égrikşelür ursukuşur bèşinç tẹri tüpirer korkinçı yèl turur kemi aktarllur ölür bo munça korkınçı adaka kirip ölgey siz bizni irinç kilgay siz (XVII-XVIII)

Tehlike olarak sunulan manzara bir okyanus içerisinde insanın başına gelebilecek olağanüstü tehlikelerdir. Bunlar canavar balık, su rengindeki dağlar, şeytanlar, anafor ve firtına şeklinde sıralanır. Mitolojik yapı içerisindeki bu okyanus manzarası samsāra dünyasındaki okyanusu işaret etmektedir. Buna göre bu okyanus ' 'ölüm okyanusu, doğum ölüm okyanusu, samsāra ya da döngü' olarak ifade edilir. Ayrıca 'varlık denizi ya da doğum ölüm denizi' olarak da tanımlanır (Soothill-Hodous 1937: 214a)' (Tokyürek 2019a: 426). Bu yolda canlı sonsuz 1zdırap içerisindedir. Burası aynı zamanda kahramanın erginliğe ulaştı̆̆ tehlikeli yoldur / yolculuktur. Başka bir deyişle Buddha'nın Buddha olma yoludur. Śākyamuni Buddha'nın 'aydınlığa' ulaşmak için 29 yaşından 35 yaşına kadar geçirmiş olduğu ruhsal yolculuk başka bir deyişle ormanda geçirmiş olduğu münzevi hayatı ve Māra 'şeytan' ile olan mücadelesi yolculuğun ne kadar tehlikeli ve zor olduğunun bir göstergesidir (Tokyürek 2019a: 73). 
Hükümdarın bu tehlikeli yolları söylemesine rağmen prensin hâlâ yolculuk yapmak için ısrar etmesi sonrasında hükümdar, prensin maceraya çıkması konusunu kesin bir dille reddeder. Prens bu 'maceraya çağrı' ya dışarıdan gelen etki neticesinde yanıt veremez. Fakat onun kendini dış dünyaya kapatması, yaşama dair olgulardan vazgeçmesi sonucunda Prens, babasını ikna eder ve o artık yolculuğa hazırdır.

ötrü kayı yarlıgkamadı barmagay sen tèp tédi ötrü tègin başın tönitip ıglayu yérde yatıp yokkaru turgalı aş aşlagalı unamadı inçe tèp tèdi yarlıg bolmaz èrser bo yèrde yokkaru yokkaru turmaz men aş aşanmaz men ölgey (XIX)

\subsection{Doğaüstü Yardım/Yol Gösterici}

Çağrıyı reddeden kahraman doğaüstü bir varlığın yardımına ihtiyaç duyar. İyi ve Kötü Prens Öyküsü'nde de çağrıyı anlamayan ya da gerçekliği fark edemeyen prens etrafındaki dilencilere hazineler dağıtmış, fakat hazinenin tükenmesinden kaynaklı olarak soylulardan zengin olma yolunu öğrenmeye çalışmıştır. Metinde özellikle kanun/öğreti bilen bir bilgenin 'cintāmaṇi'yi arayıp bulma öğüdü’ önemlidir. Çünkü prens daha önce bu cintāmaṇi’yi hiç duymamıştır. Dolayısıyla (Budist) öğretiyi bilen bir bilge kişinin çağrıyı anlamadığ düşünmek yanlış olmayacaktır. Campbell'e göre 'böyle bir figürün temsil ettiği şey kaderin iyi kalpli, koruyucu gücüdür.' (2020: 72). Prens bu sayede neyi arayıp bulacağını artık biliyordur: cintāmanii ${ }^{11}$.

yeme bir bilge nom bilir er inçe tèp tèdi tavar kazganmak ney taloy ügüzke kirip köyülteki küsüşin kanturgalı sakınsar bulunçusuz çintamani erdini bulsar kamag yértinçüdeki tınlıglarnıり küsüşin inçip (XIV-XV)

tègin inçe tèp ötünti luu ${ }^{12}$ hanlarınta çintamani erdini bulsar bar kim ülüglüg kutlug kişi ol erdini bulsar kamag tınlıglarka asıg tusu kılur anı üçün taloyka kirigseyür men tèp ötünti (XXI)

\footnotetext{
${ }^{11}$ Cintāmaṇi metinden de anlaşıldığı üzere "bütün istekleri yerine getiren t1lsımlı inci' olarak gösterilir (Soothill-Hodous 1937: 211a, 445b; Tokyürek 2019b: 193-194) ve maṇi, Buddha'nın ve onun öğretisinin saflığına işaret eder (Soothill-Hodous 1937: 191b), canlıların isteklerini yerine getiren değerli bir taştır (Soothill-Hodous 1937: 435b)'; (Tokyürek 2019b: 501-502), ayrıntılı bilgi için bk. (Tokyürek 2019b). Bununla birlikte bu cintāmaṇi kişinin kendi özü, benliğidir.

12 Metinde $l o ̈$ şeklinde olup burada düzeltilmiştir. Bk. (Wilkens 2021: 437).
} 
Campbell'e göre kahramanın yolculuğa çıkması için tüm engelleri aşması ve çağrıya cevap vermesi gerekir. Çağrıya cevap veren kahraman, tüm doğaüstü güçleri yanında bulur. Bu doğaüstü güçler, genellikle erkek olarak resmedilir ve bu kişi kahramanın ihtiyaç duyabileceği tılsımları ve öğütleri sağlayabilecek büyücü, keşiş ya da bir ihtiyar olabilir. Böyle bir yardımcının göründüğü kahraman çağriya yanıt vermiştir (Campbell 2020: 73-74). Hikâyenin devamında kahramanın yolculuğa çıkması için rehber olacak kişiler aranmaktadır. Kahramana eşlik etmek için beş yüz kişinin gelmesiyle birlikte bu beş yüz kişi seksen yaşında, kör bir ihtiyardan rehberlik konusunda yardım isterler. İhtiyar, rehberlik için kendisi gelmez, dışarıdan müdahale ile olaya dâhil edilir. Dolayısıyla hikâyede ihtiyar bilge arketipine yer verilir. Buna göre ihtiyar bilge arketipi özelliklerine sahip olan yaşlı adam/rehber, hangi yolların hedefe götüreceğini bilir, bunları da kahramana gösterir. Karşılaşabileceği tehlikeler konusunda onu uyarır ve bunlarla baş etme yolları hakkında bilgi verir. Onun hem ulvi hem de yardımsever olması, onunla tanrı arasında bir bağ kurma düşüncesini akla getirmektedir (Jung 2009: 87-98). Yaşlı adamın / rehberin de gözlerinin kör olması tanrıyla bir bağ kurduğunu işaret etmekle birlikte onun dış dünyaya karşı gözlerini kapattığını, ama bir rehber olacak kadar iç görüye sahip olduğunu gösterir.

ol üdün baranas uluşta bir edgü alp yèrçi suvçı bar erti kaç kata taloyka kirip besşer yüz erin barıp esen tükel kelmiş erti inçip sekiz on yaşayur karl erti yene èkki közi körmez erti ol besş yüz er kamugun ol körmez yèrçike ötüntiler (XXIII-XXIV)

ol üdün tègin özi barıp kolın yètip içgerü kayı han tapa kigürdi kayı han inçe tèp yarlıgkadı birkiye amrak oglumın sizine tutuzur men esen tükel kelürüy tèp yarlıkadı (XXV)

Bununla birlikte ihtiyarın, prensin 'ölüm yeri'ne gideceğini sorgulaması dikkat çekicidir. Çünkü yukarıda da belirtildiği üzere bu yol, hem tehlikelerle dolu hem de geri dönüşü mümkün olmayan bir yoldur. Prens de zaten bu yoldan dönemeyecektir.

teyrim ne muy tak bolt kim antag teyri teg erdini teg

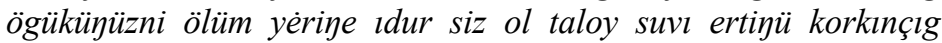
adalıg ol üküş tınlıglar barıp ölügli bir barsar yaragay mu tép ötünti (XXVI)

Hikâyenin devamında gemiler hazırlanacak, ihtiyar rehber ve beş yüz kişi eşliğinde yolculuk başlayacaktır. 


\section{4. İlk Eşiğin Aşılması}

'Kahraman, kaderin ona rehber olarak atadığı kişilerle birlikte aşırı güç bölgesinin girişindeki 'eşik muhafizı'na gelinceye dek ilerler. Bu muhafizlar, kahramanın şu anki alanının ya da yaşam ufkunun sınırlarını belirterek dünyayı dört yönden sınırlar.' (Campbell 2020: 76). Eşik muhafızları 'kahramanı çeşitli testlerle sınar ve kahramanın gelişimine, olgunlaşmasına dolaylı bir biçimde katkıda bulunurlar. Eşik muhafızı maceranın devam edebilmesi için mutlaka aşılması gereken bir engeldir. Aksi takdirde kahraman görevini tamamlamak için girmesi gereken dünyaya geçişini tamamlayamaz. Kahraman eşik muhafızını aşabilmek için doğru yönteme karar vermelidir. Eşik muhafızı güç kullanılarak alt edilebilir. Ayrıca kahraman kurnazlık yaparak, eşik muhafızını sakinleștirerek, onunla dostluk kurarak, gizli parolayı bilerek, sorduğu bilmeceyi çözerek ya da onun gibi düşünmeyi öğrenerek eşik muhafızını aşabilir' (Indick 2004: 75'ten aktaran Akgün 2008: 49). Bu hikâyede ise kahramanın yolculuğuna engel olan kişi / kişiler prensin babası ve annesidir, onlar birer eşik muhafızı olarak kabul edilebilir. Fakat prensin 1srarlı tavrı onların tüm engellemelerini ortadan kaldırır.

ol üdün kayı han yarllg yarligkadı kim taloyka barayın tèser kirinler oglum tèginke èş boluylar ne kergekin barça bèrgey biz kim yèrçi suvçı kèmiçi bar erser yeme kelzün tèginig esen tükel kelürzünler (XXI-XXIII)

kayı han inçe tèp yarligkadı birkiye amrak oglumın sizine tutuzur men esen tükel kelürüy tèp yarligkadı (XXV)

ol üdün kayı han uluş bodun ıglayu sıgtayu edgü ögli téginig uzatı üntürüp taloyka ıdtılar (XXX-XXXI)

Maceraya çıkış için en büyük engel olan baba engeli böylece aşılmış olur. Elbette hükümdar oğlunu ihtiyar rehbere ve onlarla bu yolculuğa eşlik edecek olan beş yüz kişiye emanet eder. Artık yolculuk için tüm hazırlıklar yapılmaya başlanmış ve ülkeden ayrılma vakti gelmiştir. Fakat yolculuk için hiç hesapta olmayan bir kişi de bu yolculuğa dâhil olmak için çoktan planını kurmuştur: Kötü Prens. Anne babasının rızasını kazanmak ve kendisinin de onlar tarafından sevilmesi için 'İyi Prens'e eşlik etmek ister. Onun bu yolculuğa çıkması için babasını ikna etmesi çok zor olmayacaktır. 
ol üdün ayıg ögli tégin inisi inçe tèp sakıntı ögüm kayım éçim tèginke sever meni aklayur erti amtı éçim taloyka barıp erdini kelürser takı agırlig bolgay men takı ucuz bolgay men tèp sakintı amtı birle barayın ötrü kayı hanka inçe tèp ötünti éçim tègin ölüm yérke barır ol negülük kalır men tegrim men yeme barayın edgü yavlak bolsar birle bolalım (XXVIII-XXX)

'Kötü Prens'in yolculuğa dâhil olması her ne kadar hesapta yokmuş gibi gözükse de aslında kader ağlarını çoktan örmeye başlamıştır. Sākyamuni Buddha beyaz atıyla güvenli evinden yolculuk için ayrıldığı zaman yanında kimseyi götürmemişti. Ama zihninde olanlar onunla birlikte gitmişti. Bu zihninde olanlar ise 'iyilik' ve 'kötülük'tü. Elbette bunu ispat etme gibi bir durum söz konusu değildir. Fakat bilinmektedir ki Śākyamuni Buddha ormanda geçirmiş olduğu münzevi hayatında yani ebedi yolculuğunda en çok mücadele ettiği varlık/kişi Māra 'şeytan'dır. Hatta Buddha tam aydınlanacağı zaman Māra son bir hamle yapmış ve ordularını Buddha'nın üzerine salmıştır (Tokyürek 2019a: 73). Burada da aynı şekilde 'İyi Prens'in yanında 'Kötü Prens' de yolculuğa çıkmıştır. Aslında 'Kötü Prens' ruhsal yolculuğun en büyük tehlikeleri arasında sayılır. O da tıpkı Māra'nın yaptığı gibi son bir hamle ile 'İyi Prens'e saldıracak ve onun yolculuğunu tamamlamasına ve 'aydınlığa ulaşmasına' engel olmaya çalışacaktır. $\mathrm{Bu}$ durum prensin kurtuluşa erişeceğinin de bir göstergesidir. Śākyamuni Buddha nasıl Māra'nın son hamlesini alt edip nihai kurtuluşa eriştiyse aynı şekilde İyi Prens de belki zihninde bulunan son kötülügü de bu şekilde yok edip nihai kurtuluşa erişecektir. İyi ve Kötü Prensi zihindeki yin ve yang gibi düşünmek gerekir. Çünkü Kötü Prens sevilmek için yolculuğa dâhil olmak ister ama kötülüğü ağır basar. İyi prens de belki içinde bulundurduğu son kötülüğü kardeşiyle birlikte yok edecektir.

\subsection{Balinanın Karnı}

'Büyülü eşikten geçişin bir yeniden doğum alanına geçme olduğu fikri, dünyanın her yerinde rahim imgesi olan balina karnıla simgelenmiştir.' (Campbell 2020: 86). Eşikten geçiş, kişinin kendini yok etme şeklidir. Kahraman dış dünyanın sınırlarından çıkmak yerine yeniden doğmak için içe doğru yani kendi içine gider. Bu tapınağa atılan adımdır. Tapınağın içi, balinanın karnı ya da diğerleri aynıdır. Tapınaklara giden yolların ve girişlerin çeşitli hayvanlarla kuşatılması ve korunması insanın kutsal bildiği iç dünyasıyla olmasındandır. Bunlar eşik muhafızlarıdır. Kendini 
adamış kişinin bir tapınağa giriş anında bir dönüşüm geçireceğini sergiler. Kahramanın dünyevi karakteri dışarıda kalır. İçeri girdiği zamanda kahramanın ölmüş olduğu ve onun Dünya Rahmine, Dünya Göbeğine döndüğü söylenebilir. Tapınağa giriş ile balinanın karnına giriş yaşamı yenileme eylemini belirtir. Kişinin kendi bedeninden vazgeçmesi kısacası kendini kurban etmesi gerekmektedir (Campbell 2020: 89-90). Kahraman burada dinlenir, kendi iç dünyasının muhasebesini yapar. Buradan çıktıktan sonra farklı bir dünyaya açılacağının da bilinci içindedir. Buralar çoğunlukla yer altı, mağara, orman gibi yerlerdir. Kısaca kişinin sığındığ 1 , diğer varlıklardan uzaklaştığı alanlardır. Kişinin kendi iç dünyası da aynı şekilde sığındığı tek yerdir.

ol üdün kayı han uluş bodun ıglayu sıgtayu edgü ögli téginig uzatı üntürüp taloyka ıdtılar kaltı taloy ügüzke tegip yètti kün turup kèmi yarattı yètti temir sua kèmi solap turgurtı yèttinç kün tay taylayur erken edgü ögli tègin ulug küvrüg tokıtıp inçe tèp yarlıgkadı taloy ügüzke kirür sizler kim ölüm adaka korksar aşnurak yorılylar men sizlerni küçep èlitmez men (XXX-XXXII)

kim ney unamadllar (üntemediler) künine munçulayu küvrüg tokıp yarlıg yarlıgkap kim ney üntemeser yèttinç kün temir sua açtı temir ışı g yorıdı (XXXII-XXXIII)

tègin kutı ülügi üçün adasız tudasız kaç kün içinte erdinilig otrukka tegdiler yètti kün anta tındılar yettinç kün taク adınçıg erdini yinçü kèmike tükegüçe urup tègin inçe tép yarligkadı (XXXIII- XXXIV)

Kahramanın sığındığı, belki de iç dünyasının muhasebesini yaptığı yer okyanusun kenarıdır. Balinanın karnında olan kahramanla ilgili olarak metinde sürekli yedi sayısının belirtilmesi ilgi çekici olmakla birlikte aslında oldukça yerinde tekrarlardır. Çünkü yedi sayısı 'Saṃsāra içindeki Mayā'nın da gezegensel zincir olarak yedi küresiyle ilgilidir. Bu her küre, aktif varoluşun kırk dokuz durağını oluşturan yedi evrim turunu ifade eder. Bu evrim turu, embriyonun gelişim sürecinde de vardır ve fetüsün hücresel yapıdan insana, ölümden sonra da psişik dünyanın embriyonik durumuna geçişini sağlar. Yeniden ortaya çıkmasının önünde benzer şekilde tamamen psişik koşulları deneyimler. Başka bir deyişle, biri fiziksel diğeri psişik her ikisi birbirine bağl1 embriyonik süreçte varoluşun dokuz durağına karşılık gelen evrimsel ve devrimsel kazanımlar elde edilir. Benzer şekilde, bardonun kırk dokuz günü, yedi hecenin gizeminin de sembolü 
olabilir. Hermetik yazılarda bunlar, ölümden sonraki yedi bölgedir ve her biri ara dünyada belirli bir karmaşık bilinç ilkesinin yedi unsurunu sembolize eder (Evans-Wents 2000: 109-110)' (Tokyürek 2021: 48-49). Böylece balinanın karnında bulunan kahraman ara dünyadaki (bardo) süreciyle birlikte fetüsten insana, ölümden sonra da psişik dünyanın embriyonik durumuna geçişini sağlar.

Balinanın karnında/okyanus kenarında yapılan gemi, 'ölüm ve yeniden doğum denizinden insanları dişarı taşıyan Buddha gerçeğinin gemisi'nden (Soothill-Hodous 1937: 272b) başkası değildir. Burada kahramanımız, Kötü Prens, ihtiyar rehber ve beş yüz denizciyi taşıyacak olan bu gemidir. İyi Prens ruhsal yolculuğunu yapmak için daha sonra bu gemiyi Kötü Prens'e bırakacak ve kendisi ihtiyar rehber ile yolculuğuna yürüyerek devam edecektir. Bununla birlikte bu aşamada yedi gün boyunca davulların çalınması da oldukça önemlidir. 'Davul, heyecanlandırıcı erdemi tamamıla ön plana çıkarmak' (Soothill-Hodous 1937: 274a) anlamındadır. Terim, bütün canlılara Buddha öğretisini duyurmaya ve onları kurtarmaya yöneliktir' (Tokyürek 2019a: 214). Davulun sesi ise 'doğrunun sesi ya da vaazı (Soothill-Hodous 1937: 274a), Dharma'nın gök gürültüsü, uyuşukluktan, sersemlikten uyanmış adam ve erdemin gelişmesi için uyarmak, Buddha gerçeğinin korkunç sesi (Soothill-Hodous 1937: 274a)' (Tokyürek 2019a: 214) olarak tanımlanır. Davulun yüksek sesiyle sersemlikten/uyuşukluktan uyanan kişi yedi gün boyunca dinlenir. $\mathrm{Bu}$ dinleniş elbette kişinin iç dünyasını dinlemesiyle ilgilidir. Kendi iç dünyasını dinleyen ve benliğinden sıyrılan insan balinanın karnından çıkacak ve yeniden doğacaktır. Burada ilginç olan İyi Prens ve ihtiyar rehber balinanın karnından çıkarken Kötü Prens ve beş yüz gemici balinanın karnında kalır. Onlar hiçbir zaman balinanın karnından dışarı çıkamazlar.

\section{Erginlenme}

\subsection{Sinavlar Yolu}

Kahraman yukarıda belirtilen tüm evreleri geçtikten sonra erginlenme aşamasına geçer ve bu aşamanın da ilk evresi 'sınavlar yolu'dur. Kahraman 'bir dizi sınavdan geçmek üzere tuhaf biçimde akışkan, belirsiz biçimlerin rüya dünyasında ilerler... Kahraman bu bölgeye girmeden önce karşılaştı̆̆ 1 doğaüstü yardımcının önerileri, tılsımları ve gizli araçlarından yardım almaktadır ya da insanüstü yolculuğu sırasında kendisini her yerde destekleyen iyi kalpli bir 
güç olduğunu ilk kez burada fark edebilir.' (Campbell 2020: 93). Kahraman tıpkı şamanın yolculuğu gibi çeşitli tehlikeli yollardan geçer, şaman ölüler kralının bekçilerini sakinleştirdikten sonra yeraltının hükümdarı olan Ölüm Tanrısının huzuruna çıkar. Ölüm Tanrısının saldırısına uğrayan şaman, onu çeşitli hediyelerle yatıştırır. Bu nokta, şamanın kendinden geçtiği evredir. Yolun ikinci aşamasında da yine duyular arındırılıp önemsizleştirilir, enerji ve bilgiler aşkın şeylere yoğunlaşır ve bu durum benliğin arınmasıdır. Sınavlar yolunda kahraman benliğini fark eder ve her şeyini bir kenara bırakarak katlanılmaz olana boyun eğer. $\mathrm{O}$ zaman kendinin ve karşıtının ayrı olmadığını aynı olduğunu fark eder (Campbell 2020: 95-101). Artık kahraman tüm tehlikeleri geçmiş ve benliğinde bulunan her şeyden kurtulmuştur. En önemlisi bu yolda benliğini tamamıyla öldürmüş, geride benlik adına hiçbir şey bırakmamıştır.

Bu hikâyede de kahraman asıl yolculuğuna henüz çıkmaktadır. Adaya gelen prens ve yanındakiler gemiyi inci ve mücevherlerle doldurur. Fakat prensin istediği mücevherler bunlar değildir, çünkü bu mücevherler maddiyat sağlayan ama kişinin gerçeği görmesine çok da fayda sağlamayan değersiz taşlardır. İyi Prens'in asıl yolculuğu cintāmaṇi’yi aramaya çıkmasıyla başlayacaktır. Prensin tüm amacı tüm canlıları kurtarmak, tüm canlılara fayda sağlamaktır. Bu da cintāmaṇi yani öğreti ile mümkündür.

yèttinç kün tay adınçıg erdini yinçü kèmike tükegüçe urup tègin inçe tèp yarlıgkadı amtı men bo erdini birle barsar men kamag tınlıglarka artok asig tusu kllu umagay men sizler barılar men bo muntuda yégrek çintamani erdini algalı barayın kim kayu tınlıglarka tüzü tüketi asıg tusu kılu usar men (XXXIV- XXXV)

Prens yolculuk yaptığı gemiyi ve beş yüz gemiciyi Kötü Prens'e emanet eder ve ihtiyar rehberiyle birlikte sonsuzluk yolculuğuna çıkar. Böylece prensin tehlikelerle ve engellerle dolu gerçek yolculuğu bundan sonra başlar.

ötrü kadaşı ayıg ögli téginig ötlep kèmi tutuzup yantru ıdtı (XXXV)

Prens, ihtiyar rehberi ile yalnız kalır ve rehber ile suya bata çıka gümüş adaya ve gümüş dağa ulaşır. Burada ihtiyar rehber artık yorulmuş, gücü tükenmiştir. İhtiyar yolculuğa devam edemeyeceğini anlayınca İyi Prens'e yolculuğuna yalnız devam etmesi gerektiğini söyler ve bu yalnız yolculukta karşılaşacağı 
tehlikeler olan mavi lotus çiçeği, bu lotusun altındaki zehirli yılanlar, ejderha hanının sarayının etrafındaki hendek ve bu hendekteki zehirli ejderhalar ve yılanlardır. İhtiyar rehber bunları söyledikten sonra ölür. Burada tam bir ihtiyar bilge arketipi vardır. Ayrıca onun ölmeden önce 'Buddha'nın mutluluğuna eriştiğiniz gün beni reddetmeyin.' (Hamilton 2020: 50) şeklindeki ifadesi de onun tam erginliğe ulaşmadığının bir göstergesidir, o sadece kendisine verilen görevini yerine getirmiştir.

tègin yerrçi avıçka birle ékkigü kaltılar ol üdün edgü ögli tégin yèrçi avıçka kolın yėtip yètti kün bèlçe boguzça suvda yorıp kümüşlüg otrukka tagka tegdi yerri kumı alku kümüş (XXXVXXXVI)

ötrü tınturgalı sakıntı inçip avınçka arukı yètti küçi alyudı tepreyü yorlyu umadl ötrü téginke inçe tèp ötünti oglum muntuda

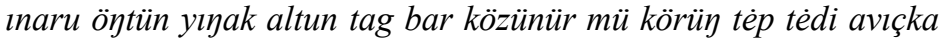
inçe tèp tédi ol altun tagka tegser siz kök lènhua körgey siz ol lènhua sayu birer agulug yılan bar agu tını ıraktın ançulayu közünür kaltı lènhua sayu tütün tüterçe ol erser ertiĐü alp ada tètir ol lénhua yolug yoguru usar siz ötrü luu hanı erdinilig balıkka ordoka teggey siz ol balık tegre yeme yėti kat karam içinte alku agulug luular yılanlar yatur anı yoguru usar siz içgerü balıkka

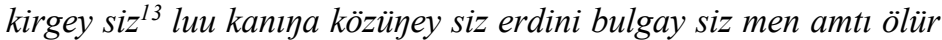
men siz yalyusklya kalır siz teyrim korkmay busanmay esen tükel teggey siz inçip kayu kün burhan kutın bulsar meni titmey edgü köni yolçı yèrçi bolup (XXXVI-XL)

Yukarıda da belirtildiği üzere ihtiyar ile prensin birlikte yapmış oldukları yolculuk esnasında kahraman ve ihtiyar rehberin gümüş bir adaya ve gümüş bir dağa ulaşması dikkat çekicidir. Gümüş Budizm'de Buddha'nın yedi mücevheri arasında sayılmasıla birlikte Budizm'de şekil dünyası olarak gösterilir. Budizm'de Skr. jāta rūpa 'şekil dünyası' anlamında olup rūpya 'gümüş' görüngü / görünüş rengi olarak kabul edilmesiyle birlikte gerçek jāta rūpa altın ile ilişkilendirilir. Fakat jâta rūpa altın ve gümüşün birleşimi olarak da gösterilir. Bununla birlikte 像色 se xiang $=$ 銀 yin kelimeleri de Budizm'de birbirine eş olarak gösterilir (Miyajima 2016: 65). Bunun yanı sıra Çin. 色像 se xiang 'maddi beden' olarak belirtilir ${ }^{14}$. Yine Çin. 生像 sheng xiang, 生似 sheng shi ifadesi de 'doğal ve benzeri', 'altın ve gümüş', altın doğal ve

\footnotetext{
${ }^{13}$ Metinde siy şeklindedir.

${ }^{14} \mathrm{http}: / /$ www.buddhism-dict.net/ddb//rad-stroke/b8272.html (05.12.2021).
} 
mükemmel metal ve renk olarak gösterilir (Soothill-Hodous 1937: 196a). Gümüş maddi hayat1, maddi/görünen bedeni ifade etmesi açısından önemlidir. Böylece ihtiyar rehber İyi Prens'i maddi/şekil dünyasının eşiğinde bırakmaktadır. Yukarıda da belirtildiği üzere ihtiyar tüm bilge eylemlerine rağmen şekil dünyasında kalmış şekilsizlik dünyasına geçiş sağlayamamıştır. Prens bundan sonra tek başına yolculuğuna devam ederek tüm tehlikeleri aşıp onun altın dağa ulaşması gerekmektedir. Bu altın dağ işte Buddha'nın erginliğe ulaştığı noktadır. Altın, Buddha'nın imajları arasında sayılır (Soothill-Hodous 1937: 280b). Ayrica altın, Buddha'nın doğal yönünü ifade eder ve bilindiği üzere altın dünyada oksitlenmeyen tek madendir. Bununla birlikte Budist literatürde Sadāśiva yarısı gümüş yarısı altından resmedilir ve tanrının yarısının gümüş ve yarısının altın olmasının nedeni erdişi yani androjin ile ilişkilidir (Eliade 2013: 299). Böylece İyi Prens altın dağa ulaşarak tanrısal özelliklere ya da Buddha'nın özelliklerine kavuşmuş olur. Prensin bu altın dağa ulaşması için lotus çiçeklerle kaplı suyu, çiçeklerin altındaki zehirli yılanları ve ejderha hanının şehrini çevreleyen yedi katlı hendek içindeki ejderhaları ve yılanları alt etmesi gerekecektir. Mavi lotuslarla kaplı bataklık, lotus çiçeği ve çiçeğin altındaki yılarlar saṃsāra dünyasından başkası değildir. Geniş bilgi için bk. (Tokyürek 2019b: 508-509). Bunun yanı sıra ejderha hanının sarayının etrafını saran yedi katlı hendekteki ejderhalar ve yılanlar ise kişinin kendi benliği/egosudur. Campbell'e göre 'ego kendini öldürebilir mi? Çünkü etrafı sarılmış Hydra'nın bir sürü başı vardır, bir başını kesince iki tane belirir, ta ki doğru merhemi sürünceye dek bu devam eder... Şimdi ejderhalar öldürülmeli ve şaşırtıcı engeller aşılmalıdır.' (2020: 101-102).

\subsection{Tanrıçayla Karşılaşma ve Baştan Çıkarıcı Olarak Kadın}

Yolculuğun tüm engelleri ve tehlikeleri aşıldıktan sonra kahraman, dünyanın kraliçe tanrıçasıyla karşılaşır ve bu ruhun mistik evliliği olarak gösterilir. Bu tapınağın sunak yerindeki ve kalbin en derin noktasının karanlığındaki krizdir. Tanrıça yaşam ateşiyle kıpkırmızıdır; dünya, güneş, uzaydaki her şey onun rahminde barınır. $\mathrm{O}$ dünya yaratıcısı, ölümsüz anne, ölümsüz bakiredir. $\mathrm{O}$ ölen her şeyin ölümüdür ve o rahim ve mezardır. O 'iyi'yi ve 'kötü’ yü birleştirir. Tanrıça zaman nehrini, yaşam akışını bir anda 
yaratır, korur ve yok eder. $\mathrm{O}$ varoluş okyanusunun ötesindeki gemidir. Tanrıça cezbeder, baştan çıkarır, kahramanın zincirlerini kırmasını sağlar. Eğer kahraman tanrıçanın arzusuna uyarsa, ikisi bilen ve bilinen, her türlü sınırlamadan kopar. Kadın duyusal maceranın yüce zirvesine götüren rehberdir. Tanrıçayla karşılaşma kahramanın sonsuzluğun örtüsü olarak kutlanan yaşamın kendisi olan aşk ödülünü kazanmak için vereceği son sınavdır (Campbell 2020: 103-111). 'Dünyanın kraliçe tanrıçasıyla mistik evlilik, kahramanın yaşam ustalığını temsil eder, çünkü kadın yaşamdır, kahraman onun bileni ve efendisidir. Kahramanın nihai deneyimini ve edimini önceleyen sınamalar, bilincini geliştiren ve onu kaç1nılmaz gelininin yani anne-yok edenin sahiplenișine katlanabilecek hâle getiren araçların gerçeğe dönüşme krizlerinin simgesidir' (Campbell 2020: 113). Kadın baştan çıkarıcıdır, 'yaşamın / doğurganlığın simgesi olan kadın, arınmış ruha katlanılmaz gelir... Kahraman bedenin tanrıçasıyla masum kalamaz artık, çünkü o günah kraliçesi olmuştur. İnsan, ceset benzeri vücut için ilgi duyduğu sürece kirlidir, doğumdan, hastalıktan ve ölümden ac1 çektiği gibi düşmanlarından da acı çeker, fakat kendini saf, iyinin ve kipırdatılamazın özü saydığı zaman özgürleşir.' (Campbell 2020: 114-115).

İyi Prens tüm engelleri ve tehlikeleri aşıp ejderhalar hanının sarayının önüne gelince önce iki kızla karşılaşır ve bu kızlar mücevherli bir ip eğirmektedir. Daha sonra dört kızla karşılaşır ve bunlar da gümüş bir ip ve en son olarak da sekiz kız ile karşılaş1lır ve bu kızlar da altın ip eğirmektedir. Üç farklı mücevherle ip eğiren bu kızların tamamı sarayın bekçileridir ve prens bu kızları aştıktan sonra ejderhalar hanının yanına ulaşacaktır.

... tegdi kapagda èkki arı kızlar turur èlgi erdinilig yıp ejirer èlginde ötrü tégin kim sizler tép ayıttı ol kızlar kapagçı biz tép tédi ötrü tégin ballk içine kirdi öytün kapagka tegdi ötrü tört körkle kırkın yürü̈ kümüs yıp enirer bo kapag közedü tururlar tègin ayıtsar kapagçı kirkın biz tédiler ötrü takı içgerü kirdi ordo kapagka tegdi ol kapagda sekiz körkle tạ arıg kzzlar sartg altun yı enirerler tégin körklerin tạlap sizler luular hanı kunçuyı mı sizler ayltsar biz ordo kapag küzetçi biz tép tédiler (XLI-XLIII)

Hikâyede dikkat çeken üç kızın üç farklı mücevher ile ip eğirmeleridir. Birinci mücevherin ne olduğu konusunda bilgi vermeyen hikâye, ikinci ve üçüncü mücevheri yine gümüş ve altın olarak gösterir. Hikâyede özellikle üç farklı mücevherden ve üç 
farklı kız grubundan bahsedilmesi önemlidir. Bu üç kızın oluşturduğu üç grup Budizm'de üç alanı/üç dünyayı ifade eder. Birinci gruptaki iki kız, arzu dünyasını simgeler. $\mathrm{Bu}$ arzu dünyası Skr. kāmadhātu ile ifade edilir ve bu alandakiler özellikle Araf'taki canlilar, pretalar, hayvanlar, asuralar ve insanlar olarak siralanabilir. Buraya arzu ve ihtiraslar egemendir (Soothill-Hodous 1937: 356a; Tokyürek 2019a: 382-383). İkinci gruptaki dört kız ise gümüşten bir ip eğirirler. Gümüş ile ilgili açıklama yukarıda da belirtildiği üzere görünen/şekil dünyası ile ilgilidir, burası da madde/şekil dünyası olarak kabul edilir. $\mathrm{Bu}$ alanda canlılar özellikle tanrılar bulunur ve onlar da çok uzun zaman hayatlarını sürdürürler (Soothill-Hodous 1937: 220b; Tokyürek 2019a: 395). Son grup ise altın ip eğiren kızlar grubudur. Bu kızlar da üçüncü alan olan şekilsizlik dünyasını ifade eder ve bu yer 'maddi olmayan, derin düşüncedeki tek zihin' olarak gösterilir (SoothillHodous 1937: 382a; Tokyürek 2019a: 403). Altın ölümsüzlüğü simgeler (Campbell 2020: 123). Başka bir deyişle Buddha'nın üç bedeni olan Saṃbhogakāya, Nirmāṇakāya ve Dharmakāya'ya bir dönüş sağlanır. Arzu dünyasından şekil dünyasına ve oradan da şekilsizlik dünyasına bir geçiş yapılır. 'Böylece değersiz bedenlere sahip olan canlılar, Buddha bedenine dönmeye çalışırlar. 'Burada amaç ruhun tekâmülüne, kurtuluşuna ve özgürlüğüne erişmeye yönelik tinsel bir durumdur. Yoginin amacı altıla aynı özden yapılmış ruhu kurtuluşa eriştirmektir' (Eliade 2013: 342)' (Tokyürek 2021: 121). Böylece prens bu alanların her birini tek tek aşarak ulaşmak istediği yere ulaşmıştır. Ayrıca burada bekleyen eşik muhafızlarının kızlardan oluşması en son şekilsizlik dünyasının kapısında bekleyen kızların da çok güzel olması dikkate değerdir. Çünkü bu durum Śākyamuni Buddha'nın erginliğe ulaşmadan önceki durumuyla uygunluk göstermektedir. Śākyamuni Buddha bodhi ağacının altında erginlenmek için oturduğunda Māra son bir hamle yapar ve tüm ordusunu Buddha'nın üstüne gönderir. Bu kızlar Buddha'yı baştan çıkaracak olan kızlardan oluşur ve bu kızlar 1zdırap, arzu ve hırs1 simgeler (Robinson-Johnson 1996: 1415; Tokyürek 2019a: 74). Hikâyede Buddha'yı baştan çıkarıcı hareketleri olmamakla birlikte ejderhalar hanının sarayına ulaşmak için muhafız olarak bu kızların bırakılması manidardır. Çünkü bu güzel kızları aşmak aslında çok da kolay değildir. 
Prens kızlardan oluşan bu üç muhafız grubunu da geçtikten sonra artık ejderhalar hanının yanına girebilir. Prensin geldiğini de ejderhalar hanına yine bu muhafiz kızlar bildirir.

ötrü tègin içgerü inçe ötüg bèrdi bo çambudvip ${ }^{15}$ yerr suvdakı baranas uluştakl han oglı edgü ögli tègin kelip kapagda turur içgerü közüyeli tèp ol üdün ol kapagçı kırkın içgerü kirip ötüntiler (XLIII-XLIV)

\subsection{Babanın Gönlünü Alma}

Kahraman yolculuğuna devam edebilmek için öfkeli ve gazaplı babasının gönlünü almak zorundadır. Babanın ego yıkıcı erginleyişinin ürkütücü deneyiminden başka bir dişi figürün yardımıyla kurtulabilen kahraman, yaşam rolleri yeterince erginleşmemiş bir babaya sahip olursa kaos ortaya çıkar. Çocuk, anne göğsünün yaygın idisinden çıkıp yetişkinlerin dünyasına geçiş yapar. Kişi ruhsal olarak babanın alanına geçer, baba oğlu için gelecekteki görevin işareti ve kızı için de gelecekteki eşi olur. Baba kahramanın büyük dünyaya geçmesini sağlayan erginleştirici rahiptir. Daha öncesinde 'iyi' ve 'kötü'nün temsilcisi anneyken artık babadır. Oğul evrenin egemenliği için babasına karşı, kız ise egemen olunan dünya 'olmak' için annesine karşı mücadele eder (Campbell 2020: 123-129). 'İdeal kişi artık insanlığından sıyrılmış ve kişiliksiz kozmik gücün temsilcisi olmuştur. İki kere doğmuştur: kendi babası olmuştur. Bu yüzden kendisi, kişiyi çocuksu 'iyi' ve 'kötü' yanılsamalarından umut ve korkudan arındıracak ve varlığın açılımının anlaşılmasıyla huzur içinde kozmik yasanın görkemliliği deneyimine geçirecek olan erginleştirici, rehber, güneş kapısı rolünü üstlenebilir.' (Campbell 2020: 129).

İyi ve Kötü Prens Öyküsü’nde ise İyi Prens gerçek babasının yanına ulaşamaz. Metinde baba figürü ejderhalar hanıdır. Sarayın bekçisi kızlar prensin geldiğini söyledikleri zaman ejderhalar hanı şöyle düşünür:

luu hanı inçe tèp sakınç sakıntı ulug küçlüg kutlug bodisavatlar èrmeser bo yèrke ney tegmegey erti ol bodisavat érinç kirzün tèp yarlıgkadı ol üdün tègin içgerü kirdi luu hanı utru ünti èlgin tuta kigürüp erdinilig orunlug üze olgurtı luu hanıђa tatıglıg sukançıg nom nomladı ulug ögrünçülüg köylin buşi berrmek asgı nomladı ol

${ }^{15}$ Metinde çımbudvıp şeklinde olup burada düzeltilmiştir. Bk. (Wilkens 2021: 220). 
luu hanı ertiyü sevinti süzülti inçe tèp tèdi ne kergek boltı kim ança emgenip bo yèrke keltiyiz (XLV-XLVII)

Ejderhalar hanı prensin bir Bodhisattva olduğunu anlar ve onun seçilmiş bir kişi olmasından kaynaklı olarak buraya kadar kolaylıkla geldiğini düşünür. Ayrıca İyi Prens'in zihninde korkutucu bir ejderha ile karşılaşacağı düşüncesi varken ejderha onun Bodhisattva olabileceği düşüncesinden dolayı onu oldukça iyi karşılar. Onu içeri çağırır ve mücevherli tahta oturtur. Prens de ejderhalar hanına öğretiyi/dharmayı öğretir, sadaka vermenin erdemini söyler. Arkasından ejderhalar hanı gönlündeki tüm kötülüklerden arınır. Böylece İyi Prens ejdehadan cintāmaṇi’yi almak için geldiği hâlde burada roller değişir ve prens ejderhanın yerine geçer. Kısaca babanın rolünü üstlenir.

bodisavat tègin inçe tèp ötünti bo yèrtinçüde kamag tınlıglar üçün burhan kutın tileyü yok çıgay irinç yarlıg tınlıglarka asag tusu kllgalı çintamani erdini kolu buşika keltim tèp ötünti (XLVIIXLVIII)

luu hanı inçe tèp yarligkadı yaragay ögre yeme bodisavatlar munçulayu erdini buşika kelmişi bar erti alkuka bérip ıdtımı sizine yeme bergey biz (XLVIII-XLIX)

Prens daha sonra ejderhadan tüm canlıları kurtarmak için cintāmaṇi’yi ister. Ejderha Bodhisattva Prense cintāmaṇi’yi vereceğini söyler. Ama belki onu denemek belki de kendisinin kurtuluşunu elde etme isteğinden dolayı ondan öğretiyi kendisine anlatmasını ister. Prens öğretiyi ejderhaya anlatır ve orada yedi gün kalır. Böylece babası rolüne bürünen ejderhanın gönlünü kazanır ve alır. Kahraman tüm arzu ve isteklerinden arınır ve artık onun için ne iyinin ne de kötünün bir değeri kalır. $O$ tüm benliğini burada birakir.

yètti kün munta èniy bizige nom nomlay tapınalım udunalım bizige asag tusu kılıy yèttinç kün erdini alıp bèriy (bèreyin) tép tedi (XLIX-L)

ol üdün edgü ögli tègin yètti kün luular tapagın udugın aşadı yèttinç kün luular hanı narata atlig luu hanı kulgakintakl çintamani erdini alıp söküp tèginke bèrti (L-LI)

Yedinci günde sınavdan geçen prense ejderha cintāmaṇi’yi kulağından çıkarak verir. Mitolojik anlatılarda kahramanın ülkesinden ayrılmasının nedeni 'büyülü nesne'yi elde etmektir. Bu amaç için yola çıkan kahraman aynı zamanda kişilik gelişimini de tamamlar. 
Ejderhalar ile savaşarak zor tecrübelerden geçen kahramanın zaferi, güçlükle elde ettiği bir hazine/büyülü nesnedir (Akça 2019: 11-12). İyi Prens ejderha ile savaşmak zorunda kalmamış aksine onun iyi niyetiyle karşılaşmıştır.

\subsection{Tanrılaştırma}

Campbell'e göre Erginlenme'nin dördüncü aşaması kahramanın tanrılaştırılmasıdır. 'Özellikle Avalokiteśvara 'acıyla bakan efendi'dir. O Buddha olma yolunda yani hiçliğe girmeden önce tüm yaratıkları aydınlanmaya ulaştıracağına yemin etmiştir. $\mathrm{O}$ da Buddha gibi sıradan kahramanların aldırışsızlığının son korkularının ötesine geçerek ulaşacağı tanrısal hâlin bir modelidir. 'Bilinç zarfi yok olduğunda o, değişimden uzaklaşır, bütün korkulardan kurtulmuş olur.' Bu tüm canlıların içindeki kahramanlık yoluyla serbest kalacak, herkesin ulaşabileceği gizildir. 'Tüm varlıklar benliksizdir.' Dünya Bodhisattva ile dolmuş ve 1ş1ldamaktadır. Fakat onu kapsamaz, dünyayı ve lotusu kapsayan odur. Ac1 ve haz onu yönlendirmez, o yönlendirir onları. Nirvāṇa'nın eşiğinde duraksama, zamanın sonuna dek vazgeçme kararı, sonsuzluk ve zaman arasındaki ayrımın ancak zorunlu olarak akılcı zihin tarafından açık kılındığının fakat karşıtlık çiftlerini aşmış olan aklın kusursuz bilgisi içinde çözüldüğünün fark edilmesini temsil eder. Zaman ve sonsuzluğun bütününün iki yönü, yani sonsuzluk mücevheri doğum ve ölüm lotusundadır.' (Campbell: 2020: 140-141). Tanr1 ya da Bodhisattva androjin bir yap1 içindedir. Örneğin Avalokiteśvara Budist kaynaklarda hem eril hem de dişil olarak resmedilir. O ikiliğin terk edildiği simgesel bir alana sahiptir. Eril ve dişil birleştirilir ve tanrısal 'birlik' oluşturulur (Campbell 2020: 143). 'İçte görünen tanrı' düşüncesiyle hepimiz acımızda acı çeken birer tanrısal varlıklar hâlini alırız. Biz ve o koruyucu baba, biriz. Koruyucu baba sıradan adamken kendini savunan, acı çeken ise Tanrı'dır. Kahraman hem babanın kendisi hem de yeniden doğuşun rahmi, annesidir (Campbell 2020: 149-150). Bodhisattva yaşamı terk etmez, sadece dikkatini görüngüsel dünyaya çevirir ve biçim ile boşluk ya da varlık ile hiçlik arasındaki bağı özümser (Campbell 2020: 152153). Bununla birlikte 'zamanın dünyası, anne rahmidir, baba tarafından verilen yaşam, annenin karanlığı ve babanın 1şığından oluşur. Ölüm sırasında yani ebediyete doğuşumuz sırasında zamanın rahminden çıkar babanın ellerine düşeriz. Bilgeler, baba- 
dan gelip ona döndüklerini anlar ve bu ikisinin aynı öz olduğunu gösterir' (Campbell 2020: 157).

İyi ve Kötü Prens Öyküsü’nde Ejderha cintāmaṇi’yi sadaka olarak verdiğini belirttikten sonra kendisinin eğer Buddha'nın sonsuz mutluluğunu bulursa kendisi gibi günahkâr canlıları kurtarmasını ister. Demek ki prens hâlâ sonsuz mutluluğu elde edememiştir. $\mathrm{Bu}$ sonsuz mutluluk için prensin hâlâ geçmesi gereken aşamalar vardır.

inçe tèp kut koltı men ulug küsüşin bo çintamani erdini alıp sizige buşi bèrür men siz kaçan burhan kutın bulsar siz meni

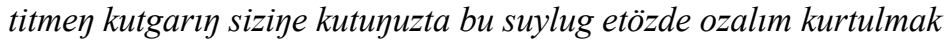
yolka teginelim (LI-LII)

\subsection{Nihai Ödül}

Kahramanın tüm engelleri kolaylıkla geçmesi ve 'büyülü nesne'yi bulması onun üstün biri, doğuştan kral olduğunu gösterir. Kahraman seçilmiş olduğu için engellerle karşılaşmaz. Nihai ödül aşamasında en önemli şey kahramanın 'uyku'ya varmasıdır. Uyku, 'alçalan bilincin bireysel yaşamın farksızlaşan enerjiye çözündüğü yer olan rüya içinde battı̆̆ 1 dipsiz uçurumdur: çözülmek ölüm demektir, ölüm de ateş bulamamaktır' (Campbell 2020: 161). Uyku hâli kişinin dünyevi gerçekliğe olan tepkisidir. Kahraman bu yolla, şifa bulur ve tedavi etmeyi öğrenir. Bununla birlikte tam iyileşme için kişinin ölümsüzlük suyunu, amṛta içeceğini içmesi gerekmektedir. $\mathrm{Bu}$ durum şaman inançlarındaki bade içme ile benzerlik gösterir. Kahraman uykusunda tam iyileşmeyi ve iyileştirmeyi öğrenir (Campbell 2020: 162-166). 'Kişisel sınırları aşmanın acısı, ruhsal büyüme acısıdır. Ejderhaları öldürüp tüm engelleri aşarken en yüksek arzusu için tanrısallık, kozmosu dolduruncaya dek büyür.' (Campbell 2020: 176).

İyi ve Kötü Prens Öyküsü’nde İyi Prens ejderhalar hanından cintāmaṇi'yi aldıktan sonra ejderhalar hanı onu okyanusa götürür.

ötrü luular hanı kalıtı èlitti taloy ügüzke kıdıgııa tegürdi (LII)

$\mathrm{Bu}$ okyanus Nirvāṇa okyanusundan başkası değildir. Yukarıda da belirtildiği üzere ejderhaya öğretinin tüm inceliklerini anlatmış, kendisi tümüyle her şeyden arınmıştır. Tüm benliğini yok eden/öldüren prens, yeniden doğum yolunu tutmuş ve artık nihai sonuca ulaşmıştır: Nirvāṇa. Nirvāṇa ifadesi için Eski Uygur Türkçesinde $\imath$ tıı kıdıg ve ol kıdıg (Tokyürek 2019a: 449-450) gibi 
ifadeler kullanılır ki canlı o kıyıya ulaşınca bütün dünyevi arzularından vazgeçecektir (Soothill-Hodous 1937: 257b). Dolayısıyla canlı tanrısal bir bedene ulaşacaktır. Artık o, sebep sonuç olmaksızın, doğum ölüm zinciriyle bağını tamamıyla koparmış ve mükemmel nirvāṇa'ya girmiştir (Soothill-Hodous 1937: 28b). Hikâye şöyle devam eder.

kaltı anta tegdükte inisi birle kavlştı èkki kadaş esen tükel kavışıp öpişti kuçuştı tglaştı ötrü slgtaştılar yene ögürdiler sevintiler (LII-LIII)

Tanrılaşma ile nihai ödül aşaması birbiriyle iç içe girmiştir. İyi Prens Kötü Prens'in yanına gelince onu öper, kucaklar. Tıpkı İnanna ve Ereştigal gibi İyi Prens ve Kötü Prens, 1şık ve karanlık, tek bir tanrıçayı/tanrıyı iki yönden temsil eder (Campbell 2020: 101). Kötü Prens İyi prens’tir ya da İyi prens Kötü Prens’tir, aslında her ikisi de birdir, tanrının ta kendisidir.

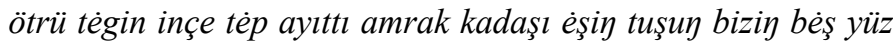
eren kança bardı esen tegdi mü inisi ayıg ögli tégin inçe tèp tédi taloy içinte yokadtı kutsuz kovılar üçün alku yokadtı alku öltiler

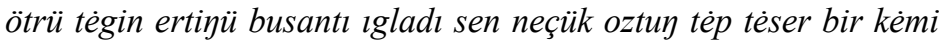
slyukın tuta üntüm tèp tédi (LIII-LIV)

Hikâyenin devamında prens beş yüz denizciyi sorar ve kötü prens onların hepsinin öldüğünü söylemesi üzerine İyi Prens tanrısal bir merhamet ile onlara üzülür, ağlar. $\mathrm{O}$ acının içinde acı çeker. Böylece tıpkı Avalokiteśvara gibi 'acımayla bakan efendi'dir.

\section{Dönüş}

\subsection{Dönüşün Reddedilişi}

Maceraya çıkış yolunda olduğu gibi dönüş yolculuğunda da bir reddediş söz konusudur. Kahraman macerasını, tüm engellere rağmen tamamladıktan sonra, maceracinın yaşam değiştiren ödülüyle birlikte dönmesi gerekir. Kahramanın bilgelik tılsımını insanların dünyasına getirmesi gerekir. Fakat kahraman sorumluluğunu reddeder. Yolculuğun sonunda kahraman, çok yorgundur ve tek istediği sonu gelmez bir uykudur (Campbell 2020: 179-180). Kahraman bazen zaferi elde etmenin rahatlığıyla rehavete kapılırken bazen de insanların arasına tekrar katılmada isteksiz davranabilir. 
Iyi ve Kötü Prens Öyküsü'nde de kahramanın yolculuğunun sonundaki yorgunluktan ve Kötü Prens'in öğüdünden kaynaklı olarak İyi Prens uykuya dalar. Uykuya dalmadan önce cintāmaṇi'yi Kötü Prens'e teslim eden İyi Prens, kardeşinin ne kadar kötü olduğunun farkında değildir ya da onun kötülüğünü unutmuştur. Kötü Prens kahramanın dönüşü için 'eşik muhafızı' gibidir ve onun geri dönüşünü engellemek için çabalayan kişidir. Bununla birlikte yukarıda da belirtildiği üzere İyi ve Kötü Prens aslında aynı kişidir. Dolayısıyla İyi Prens elde ettiği nihai ödülü ortaya çıkarma konusunda ilk olarak çok da hevesli değildir.

ötrü inisi inçe tèp tédi siz aruk siz aruklay az udı erdini maya bèriy men tutayın ötrü edgü ögli tègin başıntakl erdinig alıp inisiy bèrdi bekrü kizlep tut ogrl almazun tèp tédi ötrü udıdı ol (LV-LVI)

\subsection{Büyülü Kaçış}

Dönüşü reddeden kahraman, büyülü bir dünyaya kaçar. 'Zafere ulaşan kahraman eğer tanrı ya da tanrıçanın kutsamasını elde ederse ve toplumun yeniden yapılanması için bir iksirle birlikte dünyaya dönmekte görevlendirilirse macerasının son aşamasında doğaüstü efendisinin tüm güçleriyle desteklenir. Diğer yandan eğer ganimeti muhafızın karşı çıkışına rağmen elde ettiyse ya da kahramanı dünyaya dönme arzusu tanrılar ya da şeytanlarca uygunsuz bulunduysa o zaman mitolojik çevrimin son aşaması hareketli, genellikle gülünç bir takip olur. $\mathrm{Bu}$ kaçış, büyülü engelleme ve kurtulma mucizeleriyle karmaşıklaşabilir.' (Campbell 2020: 181-182).

Öyküdeki büyülü kaçış ise Kötü Prens'in İyi Prens'in gözlerini kör etmesidir. Buna göre;

ol üdün ayag ögli tégin köyline yek sakınçı kirdi inçe tèp tédi sakınç sakıntı ögüm kayım sönde berü meni sevmez erti éçim tèginke sever erti amtı bo erdini birle tegdükte éçim kök teyrike yoklagay men özüm itte sansız yèr körü yorımış kergek amtı munı ékki köz teglerip sançayın bo kança bargay kenti ölgey tèp sakıntı ötrü turup èkki kamış şış kıyıp èkki közine sançıp tezdi ol üdün edgü ögli tègin inisin okıyu mayradı inim kanta sen ogrı kelip èkki közümin teglerü sançtı tèp ıgladı sıgtagı balıkça agnayu (LVI-LVIII) 
Kötü Prens cintāmaṇi’yi aldıktan ve İyi Prens uykuya daldıktan sonra hedefine ulaşmak için şeytani düşüncesini harekete geçirir ve anne-babasının kendisini sevmesi için cintāmaṇi’yi alıp anne babasının yanına kendi götürecektir. Bunun için de İyi Prens'ten kurtulması gerekmektedir ki ondan kurtulmak için onun iki gözüne kamış saplar ve prensin gözlerini kör eder. Burada iki önemli nokta bulunmaktadır ki bunlardan biri Kötü Prens'in anne baba düşüncesidir. Çünkü anne ve babanın gönlünü kazanma ve onların sevgisini elde etme düşüncesi vardır. Bu olay travmatik bir yapı içerisindedir ve insan psikolojinde de anne-babanın sevgisinden mahrum olmak kişiyi kötü eylemlere iter. Hikâyede Kötü Prens kötü olduğu için sevilmemesine rağmen o, yine de anne babasının sevgisini kazanmak için başka bir kötülük yapmaktan çekinmeyecektir. İkincisi ise İyi Prens'in gözlerinin kör olmasıdır. Onun kör olması dış dünyaya ve gerçeğe karşı gözlerini kapatması anlamında olup dış dünyaya dönüşünün de engellenmesidir. Bununla birlikte İyi Prens'in kör olması aynı zamanda tanrısal bir yapıya bürünmesini ve olaylara ve olgulara karşı tanrısal bir bakışla bakmasını sağlayacaktır. O tam bir olgunluk içinde her şeyi kabullenecek ve bir teslimiyet içine girecektir.

\subsection{Dışarıdan Gelen Kurtuluş}

Dönüşü reddederek büyülü kaçışla maceranın dışına çıkmaya çalışan kahraman, yola çıkış aşamasında olduğu gibi 'doğaüstü yardım' gibi dışarıdan gelen bir kurtarıcı/yardımcı vasıtasıyla yeniden maceraya döner. Yani, dünyanın gelip onu oradan tekrar getirmesi gerekebilir. Çünkü böyle bir yerde olmanın derin saadeti, uyanık durumdaki benlik parçalanması yararına kolayca birakılamaz. Toplum, onu asla yalnız birakmaz. Mutlaka gelip onu yaşadığı yerden çıkarır ve kendi yanına dönmesi için ikna eder (Campbell 2020: 190). Bunun için en güzel örnek İnanna'nın yolculuğudur. Buna göre, İnanna kendi cennetinden inip kızkardeşi Ereştigal'in cehennemine indiği vakit, Ninşubur'a dönemeyecek olursa onu kurtarmaya gelmesini söylemiştir (Campbell 2020: 195). Kahraman topluma tekrar dönme konusunda isteksiz olabileceği gibi dişarıdan gelen eylemlerden dolayı da bu dönüşü engellenebilmektedir. Bundan kaynaklı olarak da kahraman ister dışarıdan kurtarılsın ister içeriden sürüklensin 'parçalara ayrılmış insanların içinde kendilerini tüm saydığ 1 çoktandır unutulmuş 
ortama, kendisine bahşedilen lütufla yeniden girmesi gerekmektedir' (Campbell 2020: 197).

İyi ve Kötü Prens Öyküsü’nde de durum benzerdir. Buna göre;

ötrü ol yèr suv trşl teyri bar erti tégin emgekin körü umatın

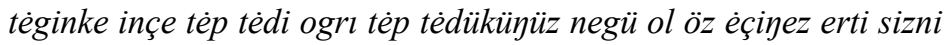
ölzün tép inçe kiltı tezip bardı amtı tglamay turuy men yérçilep èlitgey men sizni bodunka tegürgey men tèp tédi ötrü edgü ögli tégin yokkaru turd teyrisi ünteyü yol ayu bèrdi bodunka tegdi (LIX-LX)

ol üdün edgü ögli tègin kentünin kutı ülügi üçün kutı vahşiki uduzup öz kadın yèrine tegdi (LXIII-LXIV)

Gözleri kör olan prens balık gibi yerde debelenirken orada bulunan $r s ̦ i$, prensin acısına dayanamayarak onu bu şekle sokanın kardeşi olduğunu söyler ve ona yol gösterip onu gitmek istediği yere ulaştırır: insanlara/halka/topluluğa. Böylece dönüş yolunda da kahramana bir doğaüstü bir kişi/varlık gelir ve onu bu içinde bulunduğu zor durumdan çıkararak halkın, insanların bulunduğu yere götürür. Fakat ilginç olan şudur ki İyi Prens' in büyülü nesnesi olan cintāmaṇi yanında yoktur. Onu Kötü Prens'e kaptırmıştır.

tirig oztum keltüküm bo tèp ötünti ol üdün kayı han bo sav essidip kök teyri tapa ulıdı sıgtadı yüksek édiz oronluktın kodı öz kemişti ögsiredi taltı ölüg teg kamılu tüşti ür keç tèmin öglenti ötrü ol üdün baranas uluş bodunı alku busantı ıgladılar ol üdün kayı han aylg kllınçlıg ak oglın inçe tèp sézinti amrak oglum ölti erser munuy yüzin yeme körmeyin oglum savı edgü yavlak belgürginçe kınlıkta yatzun tép yarlıg boltı èlgin adakın beklep kınlıkta urdılar (LXI-LXIII)

Metin ne yazık ki eksik. Kötü Prens muhtemelen cintāmaṇi ile babasının ülkesine döner, fakat beklediği sevgiyi babasından göremez. İyi Prens'in öldüğünü öğrenen hükümdar yasını tuttuktan sonra aklı başına gelir ve Kötü Prens'i zindana attırır. Kötü Prens cintāmaṇi’ye sahip olduğu halde böyle bir muamele görmesi aslında 'büyülü nesne' olan cintāmaṇi’nin önemli olmadığını asıl önemin kişinin kendi içinde olduğunun bir göstergesidir. İyi Prens'in iyi ve tanrısal olması onun içindeki iyilik duygusundan kaynaklıyken Kötü Prens'in kötü ve şeytani olması ise yine onun içindeki kötülük ile ilişkilidir. Kötü Prens her ne kadar iyi olmaya çalışsa da iyi olmayı da kötülükle birleştirmiş ve bunda da başarısız olmuştur. Hikâyenin devamında cintāmaṇi yanında olmadığı hâlde prens tanrısal bir eda ile hareket edecektir. Bu da iyiliğin, seçil- 
mişliğin ve tanrısallığın onun içinde olduğunu gösterir. İçeride olan şeyler için dişarıdan gelebilecek hiçbir şeye ihtiyaç duymaya gerek yoktur, o zaten kişinin özünde mevcuttur.

\subsection{Dönüș Eșiğinin Așılması}

Campbell'e göre maceraya çıkışta olan ilk eşiğin aşılması gibi dönüş yolunda da kahramanın dönüş eşiğini aşması gerekir. 'Tanrısal ve insani iki dünya birbirinden farklı olarak resmedilebilir. Kahramanın dönüşü öte dünyadan bir dönüş olarak anlatılır. İki krallık da aslında birdir. Tanrıların dünyası bildiğimiz dünyanın unutulmuş bir boyutudur.' (Campbell 2020: 199). Kahraman insanların bulunduğu dünyaya gitmeli fakat kendini onlardan uzak tutmalıdır. O olayları ve olguları tanrısal bir gözle görmeye başlamıştır ve onun bu durumu koruması gerekmektedir. Aksi takdirde mükemmellik dengesi kaybolur, ruh bocalar ve kahraman düşer. Kahraman Oisin gibi ata binmeli, insanlar arasında dolaşmalı fakat asla onlara temas etmemelidir. Aksi takdirde Oisin gibi kahraman da tanrısallıktan insaniliğe bir geçiş yaşar. $\mathrm{Bu}$ da onun kutsal ruhunun düşüşü anlamında gelir (Campbell 2020: 203). 'Geri dönen kahramanın ilk sorunu, ruhu tatmin eden bir başarının ardından yaşamın süregiden neşe ve acılarını, basmakalıp yanlarını ve rahatsız edici iğrençliklerini gerçek olarak kabul etmektir.' (Campbell 2020: 200).

Canlıların/insanların dünyasına ulaşan İyi Prens gözleri görmez şekilde dolaşırken sığır sürüsüne denk gelen prensin gözlerini bir sığır yalar ve onun gözündeki şişleri çıkarır. Metinde özellikle sığırdan bahsedilmesi önemlidir. Çünkü yine doğaüstü bir varlıktan yardım gelmektedir. Hint mitolojine göre sığır ya da ineğin gübresi canlıları iyileştirir (Tokyürek 2021: 127). Fakat hikâyenin devamında prensin kör olduğunu görürüz, yani prensin gözleri iyileşmez.

kaltı balık kapagda olurur erken han udçısı bèş yüz ud süre ünti bukası aşnu ünüp tèginig yumburu yatgurup tört adakın inleyü kölitdi turdl sürüg ud kamag üntükte tilin yalgap èkki közinteki şlşıln alıp kodtı (LXIV-LXVI)

Hikâyenin devamında sığırtmaç prense kendisinin seçilmiş bir kahraman olduğunu hatırlatır. Elbette sığırtmaç durumun farkında değildir, tamamıyla bilinçsiz bir şekilde bir hatırlatlatmadır bu. Fakat prens kimliğini saklar, kim olduğunu söylemez, sıradan bir 
dilenci olduğunu ifade eder. Prens sefil bir durumdadır, sığırtmacın dediği gibi acınası bir hâli vardır. İnanna'nın tüm kıyafetlerinden kurtulması gibi bir durum söz konusudur. İyi Prens de tüm kıyafetlerinden kurtularak ve dilenci olduğunu söyleyerek tüm benliğinden/egosundan kurtulur. Bununla birlikte İyi Prens hâlâ kardeşini koruyacak kadar da tanrısal bir ruha sahiptir. Hz. İsa'nın kendini çarmıha gerenler için kurtuluş dilemesi gibi kötülüğe karşı iyilikle karşılık verir. Çünkü o, bir tanrıdır.

ötrü kapıgçı er turgurup yolta öyi olgurtı udçı er körüp inçe tèp ayltdı siz kişide adrok begrek er közünür siz negülük inçe irinç yarlıg boltuyuz tégin inçe tèp sakınç sakıntı tözümin uguşumın belgürti sözleser inim ölgey ötrü tégin toga yok çıgay buşiçi men tèp tédi (LXVI- LXVII)

Prensin diğer fânilerden farklı olduğunu anlayan sığırtmaç prense acır ve evine alır. Bu evde çok iyi karşılanan prens daha sonra istenmez, insanlar onu bir yük gibi görür ve artık kötü davranmaya başlarlar. Yiyecek verirken bile homurdanarak verirler ve prens bu evden ayrılmak ister. Sığırtmaç durumdan üzüntü duyar, fakat İyi Prens'i kararından döndüremez. Ev halkının prense kötü davranması ve prensin evden ayrılması dönüş yolundaki prens için eşiğin aşılmasıdır. $O$, dönüş yoluna böylece devam edebilecektir.

ol üdün udçı er öz evine èlitti açıntı evinteki ulug kiçigke tutuztı artok edgü açınıllar tèp bir ay artok açıntı anta kèn yeme agruk bultı keyrenü aş bèrür boltılar kaltı tègin uktı köyli yérinti ötrü

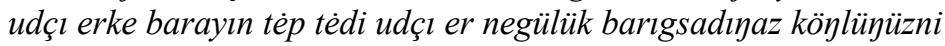
kim bertdi barmay tèp tédi (LXVII-LXIX)

\section{5. İ́ki Dünyanın Ustası}

Kahraman verdiği sınavlarla, geçtiği eşiklerle, yaşadığı tecrübelerle yola çıktığından farklı bir kendileşme, bireyleşme ve erginleşmeye ulaşmış, hangi dünyada nasıl davranacağına dair bilgiye sahip olmuştur. Campbell'e göre 'iki dünya ayrımı arasında, zamanın görünümlerinin bakış açısından nedensel derinliğinkine gidip gelme özgürlüğü ustanın becerisidir.' (Campbell 2020: 207). Kahraman hem siradan insanların bulunduğu dünyaya hem de tanrısal dünyaya çok kolay ve ani bir şekilde geçiş sağlayabilmektedir. $\mathrm{Bu}$ ani geçişler anlam dolu, kıymeti bilinecek ve düşünülecek değerdedir (Campbell 2020: 207-208). Seçilmiş kahraman, ruhsal disiplinler yoluyla, tüm kişisel hâl ve eylem- 
lerinden vazgeçmiş, doğrunun gerçekleşmesinde yeniden doğuş için gerekli olan öz-kıyımına razı olmuş ve büyük an için tam olarak olgunluğa ulaşmıştır. Kişisel arzuları tamamen yok olmuştur, yaşamaya karşı da bir isteksizlik hâlindedir, içinde olup bitecek olana tam bir teslimiyet içindedir. Kısacası artık isimsizdir. $\mathrm{Bu}$ isimsiz varoluşun son aşamasını gösteren figürler mitlerde çeşitli şekillerde gösterilmekle birlikte bazen müziği kalbi dinginleştiren mucizevi dilenci ozan rolünde de olabilir (Campbell 2020: 214-215).

İyi ve Kötü Prens Öyküsü’nün devamında sığırtmacın evinden ayrılmaya karar veren İyi Prens 'elimle çalıp ağzımla şarkı söyleyerek kendimi besleyeyim' (Hamilton 2020: 65) diyerek sığırtmaçtan bir kopuz ister. Sığırtmaç prense kopuzu getirir ve kopuz çalmakta usta olan prens bir yere oturur ve bir taraftan kopuzunu çalarken bir taraftan da şarkısını/türküsünü söyler. Büyük bir kalabak etrafına toplanır ve ona pek çok olağanüstü yiyecek ve içecekler getirirler, ülkede bulunan beş yüz dilenci doyar, mutlu olur.

\begin{abstract}
tègin inçe tèp tèdi küden ür tursar yaramaz siz maya kadaş

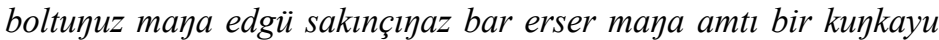
tilep kelürü̈ èlgim etizü agzım yırlayu öz igideyin ol udçı er bir kuךkau tilep kelürdi bèrdi anta uduzup ballk ortosinta beltirde kalın kuvrag ara olgurtı tégin kopuzka ertinü uz erti èlgi kopuz ètizü agzi yırlayu olurtı uluş bodun alku kuvrado yirlg taplayu esirkeyü ıglayu tegre tolı tururlar erti künine taj adınçıg tataglıg aş içkü kelürüp tapınurlar erti takı ol uluşta neçe irinç yarlig koltguçılar bar erser alku anta kuvradı bès yüz koltguçı tègin anta égidti alku menilig bolttlar (LXIX-LXXII)
\end{abstract}

Metinde dikkat çeken en önemli şey prensin kopuz çalıp şarkı söylemesidir. Kopuz ya da her hangi bir müzik aleti büyülü olarak kabul edilir ve bir hâlden bir hâle geçişi sağlar. O yüzden maṇụala törenlerinde tanrıçalar/bakire kızlar çeşitli müzik âletlerini çalarlar (Tokyürek 2021: 91). Hikâyede de İyi Prens kopuz çalıp şarkı söyleyerek büyülü bir ortam oluşturur ve iki dünyaya da hâkim olur. O tüm benliğini öldürmüş, her şeye karşı tam bir teslimiyet içindedir. Hiçbir şeye karşı direnç göstermez, o kayınpederinin ülkesinde olduğu hâlde onu kimse tanımaz, bilmez. Kısaca o artık isimsizdir. 'Yasa, kayıtsız şartsız kabul etmesiyle onun içinde yaşar' (Campbell 2020: 215). 


\subsection{Yaşama Özgürlüğü}

Dönüş aşamasının son evresi 'yaşama özgürlügü'dür. 'Eylem dünyasındaki insan, ebediyet ilkesini kaybeder, çünkü yapıp ettiklerinin sonucunda kaygılıdır, fakat onları ve meyvelerini Yaşayan Tanrı'nın dizlerine bırakarak, sanki kurban vererek, ölüm denizinin bağlarından kurtulur gibi kurtulur onlardan.' der Campbell (2020: 216). Kahraman için hiçbir şeyin önemi yoktur artık, o ebedi olma isteğinden vazgeçmiş, olaylara ve olgulara karş1 teslimiyet içine girmiştir. $\mathrm{O}$ eylemlerde dingin ve serbesttir, işi ne olursa olsun, korkunç harika Yasa'nın bilinçli aracıdır (Campbell 2020: 216-217).

İyi ve Kötü Prens Öyküsü'nde de bu durum açık şekilde görülmektedir. Buna göre;

ol üdün kadını han borlukçısı tèginig körüp inçe tèp sakıntı içgerülüg edgü yemişig kuşlar artatır üçün turkaru kınka teginür men amtı bo erig èliteyin borlukumın közedzün anta açınayın tèp ötrü tèginig èlitgeli sözledi tègin téginig kıdıgıntakl tegir üçün busanıp balık uluşta bilgelerke ayıtıp kim yeme ötkürü umadılar üküş bilge kişiler inçe tédiler ol közsüz kişi aylg bilge tètir aya ayıtıy ol borlukçı er közsüz kişi èlitiy anta al çeviş ayu bèrge men yémişigin kuş kuzgun artatmagay ötrü yémişlikçi er èliteyin tèp tédi ötrü tégin ol besş yüz koltguçılarag aşın suvın tonı etüki kopı tüketi kıltı barçaka humaru sav kodtı èkkileyü silerni körüşmegey men kaçan burhan kutın bulsa men silerni barça anta kutarga men tèp tédi ötrü ol üdün ol bėş yüz koltguçılar bo savag esşidip ulıdılar sigtadılar kaltı buzagu sın itürmiş ỉek teg ulıyu inçe tèp ötüntiler ögsüz ögi kaysız kayı siz boltuyuz amtı bizni irinç yarlıg kılıp kança barır siz ol üdün tègin inçe tèp tédi yarlıkkadı bo yértinçü törösi antag ol amrak yeme adrlur sevig yeme şeşilür tèp tédi ötrü tégin ol borlukçı er birle bardı borlukta tegmişte borlukçı erke

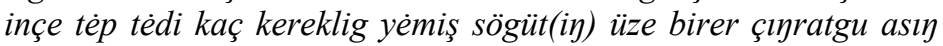

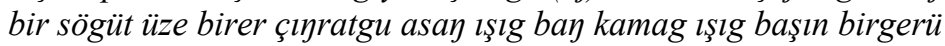
bap meniy èligde uruך kuş kuzgun konsa ışıgag tartgl men sögüt tèpregey kuşlar konmagı yèmişinez artamagay tèp tédi (LXXIILXXX)

İyi Prensin kayınpederinin bahçıvanı prensi görür ve onu sarayın bahçesine götürüp meyvelere zarar veren kuşlardan kurtarmasını ister. Bunun üzerine ozana/prense talebini belirten bahçıvan her hangi bir dirençle ya da karşı çıkmayla karşılaşmaz. Prens bahçıvanın teklifini hemen kabul eder ve doyurduğu, mutlu ettiği dilencilerin tüm isteklerini tekrar yerine getirerek bahçıvanla sarayın bahçesine doğru yol alır. Zaten bahçıvan kuşlardan kur- 
tulmak için ülkenin tüm bilgelerinden yardım istemiş ama o bilgeler kör ozanı/prensi işaret etmişlerdir. Ozan/prens bahçıvanla birlikte sarayın bahçesine gider ve kuşları kovma yöntemini bahçıvana anlatır. Hikâye burada son bulur. Hikâyede prens, eylemlere karşı tam bir teslimiyet içindedir, o hiçbir şeye karşı direnç göstermez, tamamıyla eylemlere karşı dingin ve serbesttir. Görüldüğü üzere ozanlıktan bahçıvanlığa bir geçiş yapmıştır, muhtemelen başka işleri de kabul edecektir. Çünkü o yukarıda da belirtildiği üzere korkunç harika Yasa'nın bilinçli aracından başka bir şey değildir. Bununla birlikte prensin gözleri kördür, iyileşmemiştir. Yukarıda da belirtildiği üzere prens artık sıradan insanların bulunduğu dünyaya gözlerini sonsuza kadar kapamış, bakışını başka yöne çevirmiştir.

Sonuç: Tanrısal bedene sahip, sonsuz mutluluğu içinde cennetinde yaşayan insanın buradan kovulması onu ölümlü, sefil ve 1zdıraplarla dolu bir hayata itmiştir. Artık her şey onun için acı ve 1zdıraptır. Canlının, daha doğrusu bilinçli/farkındalığı yükssek insanın bu ızdırap okyanusundan kurtulması gerekir. Bu kurtuluş sadece kendi kurtuluşu olabileceği gibi kendi dışındaki tüm varlıkların da kurtuluşunu sağlamak üzerine olabilir. Fakat bunu sağlayacak yüksek erdeme sahip olan kahramanlar, doğaüstü bir güç/tanrı tarafından seçilmiştir. Böylece mitlerde/edebi metinlerde yer alan seçilmiş kahramanlara büyük bir görev verilir ve bu görev doğrultusunda da kahraman bir ruhsal bir yolculuğa çıkar. Çünkü önce kendisinin ruhsal olgunluğa/erginliğe kavuşması, arkasından tüm canlıları kurtarması beklenmektedir. $\mathrm{Bu}$ doğrultuda Joseph Campbell'in Kahramanın Sonsuz Yolculuğu adlı çalışmasında yer alan kahramanın yolculuğundaki aşamalar $\dot{I y i}$ ve Kötü Prens Öyküsü'ndeki İyi Prens'in yolculuğundaki aşamalara denk düşmektedir. Śākyamuni Gautama Buddha'nın yolculuğuyla benzerlik gösteren İyi Prens'in öyküsü kaotik bir ortamın tasviriyle başlar. Bu kaotik/kriz ortamından büyük ızdırap ve acı çeken kahraman maceraya çağrılmıştır. $\mathrm{O}$ artık kendisine çizilen kaderini yaşamak için yolculuğa çıkmaya adaydır. Seçilmiş kahraman, kendinin böyle bir kader için seçildiğini bilmese de bilinçsizce bu doğrultuda hareket edecek, doğaüstü güçler de ona bu yolculuk için yardımcı olacaktır. Bunu yanında gerek kendinin farkındalığının olmamasından ve gerekse dış engellerden kaynaklı olan maceraya 
çıkışın reddi, özellikle ihtiyar bilge arketipiyle ortadan kaldırılır ve bilge kişi onun ihtiyacı olan ve arayıp bulması gereken mücevheri söyler. $\mathrm{Bu}$ da kahramanın yolculuğa devam edeceğinin bir göstergesidir. Oğullarının yolculuğa çıkacağını öğrenen anne baba ise bu yolculuğa engeldir ve onların yolculuk için ikna edilmesi ilk eşiğin aşılmasıdır. Prensin kendine yol gösteren kör, yaşlı rehber, beş yüz gemici ve Kötü Prens ile gemi yapımı esnasında okyanus kenarında beklemesi bir bebeğin anne karnında geçirdiği süreçle aynıdır. O da yeni hayatına doğmak için okyanus kıyısında bekler. $\mathrm{Bu}$ bekleme sürecinde de özellikle yedi rakamının sürekli tekrar edilmesi embriyonik yapıyla ilişkilidir. İyi Prens bu süreci geçirinde artık erginlenme için yolculuğuna çıkabilir. Bu yolculuk tehlikelerle ve engellerle doludur. Lotuslarla kaplı su, zehirli yılanlar ve zehirli ejderhalar. Bu tehlikeleri aşan kahraman bu defa eşik muhafızı görevindeki tanrıçalarla ya da baştan çıkarıcı kadınlarla karşılaşır. Bunların her birinin eğirdiği ipler farklı hayat şekillerinin işaretidirler. Ejderhalar hanına ulaşan kahraman ondan cintāmaṇi’yi ister ve o da öğretiyi anlatması karşılığında cintāmaṇi’yi verir, bu aşama babanın gönlünü almadır. Bundan sonra İyi Prens tanrısal özelliklere sahiptir, o tüm benliğini orada bırakmıştır. Ejderhalar hanının prensi okyanusun kıyısına bırakması ise nihai ödüldür/nirvāṇadır. Nihai ödülünü elde eden kahramanın geri dönmesi gerekir. Fakat kahraman dönüşü reddeder. Bunun için de kahraman rehavete kapılarak uykuya dalar. Uykuya dalan İyi Prens'in gözlerini Kötü Prens kamış ile oyar, bu durum da onun büyülü kaçışını ifade eder. Bu aynı zamanda İyi Prens'in dış dünyaya karşı gözlerini tamamen kapattığının ve her şeyi tanrısal gözle gördüğünün bir göstergesidir. Onu bu durumdan çıkaracak olan yine doğaüstü güçlere sahip bir rehberdir. Kendine yardımcı olan bu rehber sayesinde insanların bulunduğu yere gelir, bir sığırtmaca misafir olur. Fakat burada da istenmeyince yolculuğuna devam eder. Bu da dönüş için aşılması gereken diğer bir eşiktir. İyi bir kopuz ustası olan İyi Prens, insanlar arasında kopuzunu çalıp şarkısını söyler, böylece büyülü bir dünya oluşturur ki bu onun iki dünyanın da ustası olduğunun işaretidir. Prens artık tüm eylemlere karşı tam bir teslimiyet hâlindedir. $O$, mutlak sükûneti ve teslimiyeti öğrenmiştir. $O$, tüm benliğini öldürmüş, iç huzura ulaşmıştır. Kısacası özgürlüğü elde etmiştir. 


\section{KAYNAKÇA}

Akça, Hilal, 2016: Kemal Tahir'in Romanlarında Yolculuk Arketipi, Erciyes Üniversitesi, Sosyal Bilimler Enstitüsü Yayımlanmamış Doktora Tezi.

Akça, Hilal, 2019: 'Kemal Tahir'in Milli Mücadele Konulu Romanlarında "Seçilmiş Kahraman" ve "Büyülü Nesne", Türkiyat Mecmuası, Cilt-29 Sayı-Özel Sayı, 1-24.

Akgün, Özgür Uğraş, 2008: Kahraman Olgusunun Çizgi Romandan Sinemaya Uyarlamadaki Görünümü: Tarkan ve Conan, İstanbul Üniversitesi, Sosyal Bilimler Enstitüsü Yayımlanmamış Doktora Tezi.

Buswell, Robert E., Donald S. Lopez, 2014: The Princeton Dictionary of Buddhism, Princeton University Press, Princeton and Oxford.

Campbell, Joseph, 2020: Kahramanın Sonsuz Yolculuğu, (Çev. Sabri Gürses), İthaki Yayınları, İstanbul.

Campbell, Joseph ve Bill Moyers, 2020: Mitolojinin Gücü, Kutsal Kitaplardan Hollywood Filmlerine Mitoloji ve Hikâyeler, (Çev. Zeynep Yaman), MediaCat Kitapları, İstanbul.

Eliade, Mircea, 2013: Yoga, Ölümsüzlük ve Özgürlük, (Çev. Ali Berkay), Kabalcı Yayınevi, İstanbul.

Eliade, Mircea, 2018: Şamanizm, Illk Esrime Teknikleri, (Çev. İsmet Birkan), İmge Kitabevi, Ankara.

Eliade, Miercea, 2020: Ebedi Dönüş Miti, (Çev. Ayşe Meral), Dergâh Yayınları, İstanbul.

Evans-Wentz, W.Y. 2000: The Tibetan Book of the Dead, Published by Oxford University Press, New York.

Hamilton, James, 2020: Budacı İyi Kalpli ve Kötü Kalpli Prens Masalının Uygurcası, Prens Kalyānaṃara ve Pāpaṃkara Hikâyesi, (Çev. Ece Korkut-İsmet Birkan), Türk Dil Kurumu Yayınları, Ankara. 
Jung, Carl Gustav, 2009: Dört Arketip, (Çev. Zehra Aksu Yılmazer), Metis Yayınları, 3. Baskı, İstanbul.

Miyajima Junko [宮嶋 純子], 2016: 日中四分律論書における語 義解釈の比較 一 元照『資持記』と照遠『資行鈔』を中 心としてー[Nitchū Shiburitsuronsho Ni okeru gogi kaishaku no hikaku -moto Teru "shi ji-ki" to Teru tō “motoyuki shou” O chūshin to shite-], 関西大学東西学術研 究所 [Kansaidaigaku tōzai gakujutsu kenkyūjo], 61-77.

Öge, Serdar, 2005: "Düzen Mi Düzensizlik (Kaos) Mi? Örgütsel Varlığın Sürdürülebilirliği Açısından Bir Değerlendirme", Selçuk Üniversitesi Sosyal Bilimler Enstitüsü Dergisi, (13), 285-303.

Rinpoche, Venerable Khenchen Thrangu, 1993: The Twelve Links of Interdependent Origination, The Namo Buddha Seminar, Glasgow, Scotland.

Robinson, Richard H., Willard L. Johnson, 1996: Thānissaro (Bhikkhu), Buddhist Religion: A Historical Introduction, Wadsworth/Thomson Learning.

Röhrborn, Klaus, 2010: Uigurisches Wörterbuch, Sprachmaterial der vorislamischen türkischen Texte aus Zentralasien, Neubearbeitung- I. Verben. Band 1: ab-ëzüglë-. Stuttgart.

Röhrborn, Klaus, 2015: Uigurisches Wörterbuch, Sprachmaterial der vorislamischen türkischen Texte aus Zentralasien Neubearbeitung- II. Nomina-Pronomina-Partikel Band 1: aasvık. Orientalistik, Franz Steiner Verlag.

Röhrborn, Klaus, 2017: Uigurisches Wörterbuch, Sprachmaterial der vorislamischen türkischen Texte aus Zentralasien Neubearbeitung- II. Nomina-Pronomina-Partikel Band 2: aš - ëžük. Orientalistik, Franz Steiner Verlag.

Soka Gakkai 2002: The Soka Gakkai Dictionary on Buddhism, Hardcover. 
Soothill, William Edward, Lewis Hodous, 1937: A Dictionary of Chinese Buddhist Terms with Sanskrit and English Equivalents and a Sanskrit-Pali Index, Kegan Paul, Trench, Trubner \& Co, London.

Sugiki, Tsunehiko, 2016: "Oblation, Non-conception, and Body: Systems of Psychosomatic Fire Oblation in Esoteric Buddhism in Medieval South Asia", In (Richard K. Payne \& Michael Witzel ed.) Homa Variations: The Study of Ritual Change across the Longue dur'ee, Oxford University Press, 167-213.

Tekin, Şinasi, 1980: Maitrisimit Nom Bitig, 1. Transliteration, Übersetzung, Anmerkungen, 2. Analytischer und rückläufiger Index, Die Uigurische Übersetzung eines Werkes der Buddhistischen Vaibhāśika-Schule, Berlin.

The Encyclopedia of Religion, Mircea Eliade editor in chief, 1-16 volume, Macmillan Publishing Company, Newyork, 1987. (ER)

Tokyürek, Hacer, 2019a: Eski Uygur Türkçesinde Budizm ve Manihaizm Terimleri, Türk Dil Kurumu Yayınları, Ankara.

Tokyürek, Hacer, 2019b: "Eski Uygur Türkçesinde Maṇi, Cintāmani”, Ahmet Caferoğlu Hatıra Kitabı, Editörler: Fikret Turan, Özcan Tabaklar, İstanbul Üniversitesi, İstanbul, 499514.

Tokyürek, Hacer, 2021: Eski Uygur Türkçesinde Tanrısal İnsan Anatomisi ve Fizyolojisi, Kimlik Yayınları, Kayseri.

Wilkens, Jens, 2021: Handwörterbuch des Altuigurischen Altuigurischen-Deutsch-Türkisch. Göttingen: Universitätsverlag Göttingen.

\section{Kisaltmalar}

ER The Encyclopedia of Religion, Mircea Eliade editor in chief, 1-16 volume, Macmillan Publishing Company, Newyork, 1987. 


\section{Web Kaynakları}

https://sozluk.gov.tr/ (Erişim tarihi: 22.11.2021).

http://www.buddhism-dict.net/ddb//rad-stroke/b8272.html (05.12.2021). 